\title{
Contaminant concentration versus flow velocity: drivers of biodegradation and microbial growth in groundwater model systems
}

\author{
Michael Grösbacher • Dominik Eckert • Olaf A. Cirpka · Christian Griebler $\mathbb{D}$
}

Received: 31 July 2017 / Accepted: 23 February 2018/Published online: 28 February 2018

(C) The Author(s) 2018. This article is an open access publication

\begin{abstract}
Aromatic hydrocarbons belong to the most abundant contaminants in groundwater systems. They can serve as carbon and energy source for a multitude of indigenous microorganisms. Predictions of contaminant biodegradation and microbial growth in contaminated aquifers are often vague because the parameters of microbial activity in the mathematical models used for predictions are typically derived from batch experiments, which don't represent conditions in the field. In order to improve our understanding of key drivers of natural attenuation and the accuracy of predictive models, we conducted comparative experiments in batch and sediment flow-through systems
\end{abstract}

Electronic supplementary material The online version of this article (https://doi.org/10.1007/s10532-018-9824-2) contains supplementary material, which is available to authorized users.

M. Grösbacher · C. Griebler $(\square)$

Helmholtz Zentrum München - German Research Center for Environmental Health, Institute of Groundwater Ecology, Ingolstädter Landstrasse 1, 85764 Neuherberg, Germany

e-mail: griebler@helmholtz-muenchen.de

D. Eckert · O. A. Cirpka

Center for Applied Geoscience, University of Tübingen,

Hölderlinstrasse 12, 72074 Tübingen, Germany

Present Address:

D. Eckert

Ingenieurgesellschaft Prof. Kobus und Partner GmbH,

Heßbrühlstrasse 21D, 70565 Stuttgart, Germany with varying concentrations of contaminant in the inflow and flow velocities applying the aerobic Pseudomonas putida strain F1 and the denitrifying Aromatoleum aromaticum strain EbN1. We followed toluene degradation and bacterial growth by measuring toluene and oxygen concentrations and by direct cell counts. In the sediment columns, the total amount of toluene degraded by $P$. putida F1 increased with increasing source concentration and flow velocity, while toluene removal efficiency gradually decreased. Results point at mass transfer limitation being an important process controlling toluene biodegradation that cannot be assessed with batch experiments. We also observed a decrease in the maximum specific growth rate with increasing source concentration and flow velocity. At low toluene concentrations, the efficiencies in carbon assimilation within the flowthrough systems exceeded those in the batch systems. In all column experiments the number of attached cells plateaued after an initial growth phase indicating a specific "carrying capacity" depending on contaminant concentration and flow velocity. Moreover, in all cases, cells attached to the sediment dominated over those in suspension, and toluene degradation was performed practically by attached cells only. The observed effects of varying contaminant inflow concentration and flow velocity on biodegradation could be captured by a reactive-transport model. By monitoring both attached and suspended cells we could quantify the release of new-grown cells from the 
sediments to the mobile aqueous phase. Studying flow velocity and contaminant concentrations as key drivers of contaminant transformation in sediment flow-through microcosms improves our system understanding and eventually the prediction of microbial biodegradation at contaminated sites.

Keywords Groundwater - Biodegradation · Aromatic hydrocarbons - Natural attenuation . Pseudomonal putida $\mathrm{F} 1 \cdot$ Aromatoleum aromaticum EbN1

\section{Introduction}

Groundwater is one of the most important resources of drinking water, accounting for $70 \%$ of public water supply in Germany. It is increasingly threatened by pollution (Bauer et al. 2008; Foght 2008; Rabus and Widdel 1994; Silva-Castro et al. 2013; Vieth et al. 2004). For the design of reliable and cost-efficient bioremediation methods we need to understand the controls and limitations of the biodegradation potential of natural microbial communities in aquifers (Meckenstock et al. 2015).

Petroleum hydrocarbons belong to the most abundant contaminants in aquifers (Rüegg et al. 2007; Meckenstock et al. 2004; Vieth et al. 2004; Meckenstock et al. 2010). Among them, the monoaromatic compounds benzene, toluene, ethylbenzene, and xylene (BTEX) are of major concern due to their toxicity (Bombach et al. 2009; Meckenstock and Mouttaki 2011), relatively high solubility and mobility (Chapelle 2000; Foght 2008), and broad use. BTEX compounds such as toluene have repeatedly been used as model chemicals in lab and field studies, since aerobic and anaerobic degradation pathways are known and bacterial cultures of key degraders are easily available (Meckenstock et al. 2004; Fischer et al. 2006; Mak et al. 2006; Foght 2008).

The biodegradation of BTEX in aquifers has frequently been observed. Both monitored and enhanced natural attenuation (MNA and ENA, respectively) are applied as sole remediation strategy for these compounds. Nonetheless, the ecology of the degrading microorganisms is hardly understood and thus the real biodegradation potential under in situ conditions remains unknown. Recent studies on the biodegradation of aromatic hydrocarbons in flowthrough lab-studies and in the field shed some light on the limitation of biodegradation by transverse dispersive mixing (Anneser et al. 2008, 2010; Bauer et al. 2008, 2009; Eckert et al. 2015). Only if both the electron donor and a favorable electron acceptor are available, bacteria can degrade the contaminant. As a result, biodegradation activities are concentrated along the fringes of contaminant plumes at quasisteady state (Anneser et al. 2008; Bauer et al. 2008). However, even if mixing does not control biodegradation, the interdependencies between contaminant transport, microbial transformation of the contaminants, microbial growth, and microbial transport hamper the predictability of biodegradation (Meckenstock et al. 2015).

Biodegradation coupled to bacterial growth can be simulated using analytical and numerical models. The biokinetic model parameters are commonly derived from batch experiments. Batch reactors are perfectly mixed closed systems with large water-to-solid ratios. Typically, comparably high contaminant concentrations are applied in incubation experiments. The substrate is usually the only limiting factor (Hofmann et al. 2016). In comparison, porous aquifers are open systems with small water-to-solids ratio and incompletely mixed. They are often affected by transient flow conditions and a dynamic contaminant load. While the activity of bacteria is supposed to be high and growth is fast in liquid batch systems due to the excess of the chosen electron acceptor and nutrients as well as continuous mixing, it is currently unclear how flow-through conditions, such as the flow velocity, and the sediment matrix influence biodegradation and microbial growth. The yield (i.e. the substrate carbon converted into biomass carbon) has been reported to be as high as 0.5 to 0.8 in batch and chemostat cultures dependent to the substrate applied (Ho and Payne 1979; Payne and Wiebe 1978, and references therein), while data from natural aquatic systems hint at considerably lower values (del Giorgio and Cole 1998; Hofmann and Griebler 2018). The sigmoid growth curve in batch cultures reflect exponential microbial growth followed by a plateau in cell density, mainly governed by the depletion of the substrate. In sediment flow-through systems, bacteria suspended in the mobile aqueous phase and attached to the sediment surfaces coexist and partition. In fact, in aquifers the majority of bacteria $(>99 \%)$ are usually found 
attached to the sediments (Griebler and Lueders 2009). Dependent on the continuous substrate load, a balance of microbial biomass between sediment and pore water is expected to establish (Griebler et al. 2002; Zhou et al. 2012). Various other factors, such as temperature, $\mathrm{pH}$, availability of an energy source, quality of the substrate, toxicity, availability of terminal electron acceptors, and microbial food web interactions influence in situ microbial growth and contaminant degradation (Chapelle 2000; Meckenstock et al. 2015).

The discrepancy in conditions between flowthrough and batch systems consequently raises the question how representative batch-derived rate coefficients of biodegradation and microbial growth are. Empirical findings regarding the comparability of biodegradation in batch and flow-through systems are ambiguous. While some studies reported that batchderived biokinetic parameters adequately described biodegradation in flow-through systems (e.g., Kelly et al. 1996; Schirmer et al. 2000), others observed significant deviations (e.g., Simoni et al. 2001; Ballarini et al. 2014). In order to clarify the influence of flow conditions on biodegradation and microbial growth, we conducted a series of growth experiments using toluene as a model contaminant in batch systems and flow-through sediment microcosms applying different toluene concentration and different flow velocities with the aerobic toluene degrader Pseudomonas putida strain $\mathrm{F} 1$, the anaerobic denitrifier Aromatoleum aromaticum strain EbN1, and a natural microbial community from aquifer sediments. Regular measurements included the concentrations of toluene, oxygen, and cell numbers. By performing experiments in numerous replicated mini sediment columns that were successively sacrificed in the course of the experiments, we could also follow growth of the attached microbes over time. All experimental data were analyzed by reactive-transport modeling considering mobile (pore-water) and immobile (sediment) bacteria. We chose toluene as the model contaminant because well characterized toluene-degrading bacterial strains are available, but we expect that the qualitative findings of this study are applicable to the degradation of other aromatic hydrocarbons too.

\section{Materials and methods}

Bacteria strains and media

We used the toluene-degrading strains Pseudomonas putida F1 (aerobic) and Aromatoleum aromaticum EbN1 (denitrifying) as model organisms. Pre-cultures of both strains were grown in $100 \mathrm{~mL}$ serum bottles at room temperature $\left(20^{\circ} \mathrm{C}\right)$ in the dark with $70 \mu \mathrm{M}$ toluene as the sole carbon and energy source. The groundwater medium was a bicarbonate-buffered freshwater medium (Widdel and Bak 1992) prepared oxic-for experiments with $P$. putida-or anoxicfor experiments with A. aromaticum as described elsewhere (Bauer et al. 2008, 2009). For batch experiments, we amended the respective medium with varying concentrations of toluene in closed serum bottles $(100 \mathrm{~mL})$ before inoculation with the bacteria. For A. aromaticum strain EbN1, the medium was autoclaved under $\mathrm{N}_{2}$ atmosphere and cooled down flushing the headspace with $\mathrm{N}_{2} / \mathrm{CO}_{2}$ (80:20). The medium was then transferred to serum bottles avowing oxygen penetration. Again the headspace in the serum bottles was flushed and replaced by $\mathrm{N}_{2} / \mathrm{CO}_{2}(80: 20)$ before capped with Viton stoppers. Toluene $(99.5 \%$; Aldrich, USA) was injected with a sterile glass syringe through the Viton stoppers to obtain concentrations between $10 \mu \mathrm{M}$ and $1 \mathrm{mM}$ in the liquid phase.

In the sediment column experiments, we provided two media, one containing the electron donor (toluene) and the other the electron acceptor (oxygen or nitrate). They were mixed directly at the column inlet to avoid growth of bacteria back into the medium reservoirs (Hofmann et al. 2016). In experiments with $P$. putida $\mathrm{F} 1$, one medium was oxygenated while the other was anoxic but contained toluene. With A. aromaticum $\mathrm{EbN} 1$, both media were oxygen-free, one containing toluene and the other nitrate. The media were contained in gastight and inert $5 \mathrm{~L}$ Tedlar bags (SKC, PA, USA) without headspace and protected from light.

\section{Batch experiments}

Both strains were inoculated at a ratio of 1:10 from pre-cultures into $100 \mathrm{~mL}$ serum bottles carrying $70 \mathrm{~mL}$ of fresh medium amended with toluene (10 $\mu \mathrm{M}$ to $1 \mathrm{mM}$ ) as sole carbon and energy source, either saturated with oxygen and an oxic headspace or 
with anoxic medium amended with nitrate $(10 \mathrm{mM})$ and oxygen-free $\left(\mathrm{N}_{2} / \mathrm{CO}_{2}\right)$ headspace. Aerobic degradation experiments were incubated at a shaker $(120 \mathrm{rpm})$ to ensure replenishment of oxygen from the headspace into the medium. We conducted incubations at room temperature in the dark and regularly collected samples for the analysis of toluene (GC-MS analysis), total cell counts (OD measurements, FACS analysis), and measurement of cell size (epifluorescence microscopy). Measurements were obtained by aseptically subsampling the liquid phase with a syringe through the Viton stopper.

\section{Column experiments using sterile aquifer sediments}

We packed mini sediment columns (material: glass, total length: $3.5 \mathrm{~cm}$, active inner length: $1.6 \mathrm{~cm}$, inner diameter: $1.34 \mathrm{~cm}$; Fig. 1) submerged in water with sterile natural aquifer sediment with a grain size ranging from 200 to $630 \mu \mathrm{m}$ and closed them by Viton stoppers. Packed, the columns had a sediment volume of about $2.3 \mathrm{~mL}$. The in- and outflow occurred through stainless-steel capillaries in the stoppers. The flow direction was from the bottom to the top. We ran twelve columns in parallel for each treatment and maintained flow-through by means of multi-channel peristaltic pumps (Ismatech, Wertheim, Germany) using Fluran tubing. All columns carrying sterile sediment were inoculated once with the same precultured strain containing a cell density of approximately $10^{4}$ to $10^{5}$ cells $\mathrm{mL}^{-1}$. We used $1 \mathrm{~mL}$ of the pre-cultured strain as inoculum in each column and left it to stand in the column for 10 min before turning on the supply of cell-free medium from the reservoir. Toluene concentrations continuously supplied to the columns ranged from 30 to $100 \mu \mathrm{M}$. The standard flow rate was set to $3.2 \mathrm{~mL} \mathrm{~h}^{-1}$. Because the porosity of the sediment was 0.3 , the flow rate corresponded to a water residence time of $12.7 \mathrm{~min}$ and a flow velocity of approximately $1.8 \mathrm{~m} \mathrm{day}^{-1}$. Overall, we tested flow rates ranging from 1 to $6.6 \mathrm{~mL} \mathrm{~h}^{-1}$. We collected water samples for the analysis of toluene (GC-MS analysis), total cell counts (FCM analysis), and occasional cell size measurements (epifluorescence microscopy) directly at the column inlet and outlet into small HPLC vials sealed with Teflon coated septa. The oxygen concentration within the columns was monitored by an optode technique using three spots of oxygen-sensitive foil glued to the inner wall of the glass columns. At various time points, we sacrificed columns to analyze the abundance and size of bacterial cells attached to the sediment. We determined the length and width of the cells via epifluorescence microscopy and subsequently calculated the biovolume of the cells. We divided sediments from the columns into three fractions of equal size using a sterile spatula, resulting in a bottom, a middle, and a

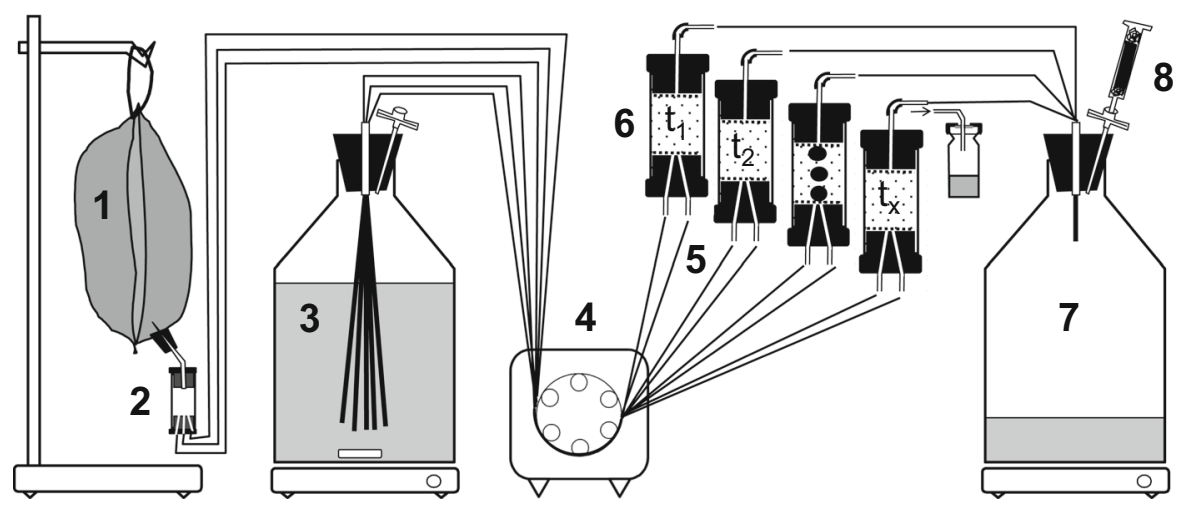

Fig. 1 Setup of a mini sediment column experiment. (1) Gastight and inert Tedlar bag with anoxic medium/groundwater amended with toluene. (2) Transport of the medium via a stainless steel capillary to a splitter which feeds the capillaries/tubes that supply the individual sediment columns. (3) Oxic medium/groundwater is supplied from a reservoir bottle. (4) Multi-channel peristaltic pump. (5) Mixing of the two media come at the inlet of (6) the sediment columns. Columns are capped by Viton stoppers. At periods where there is not sampling of column outflow, the medium is transported to (7) a waste container. Mini sediment column 3 shows three spots of oxygen sensitive foil (PRESENS, Regensburg, Germany) mounted to the inner wall of the glass cylinder for non-invasive monitoring of the oxygen content in the sediment pore water (modified from Hofmann et al. 2016) 
top fraction, each representing $1 / 3$ of the column volume (Fig. 1).

Column experiments with active aquifer sediment

In order to compare the growth kinetics of the selected model strains to those of a natural consortium, we performed flow-through experiments in columns packed with fresh natural aquifer sediment, which we infiltrated on-line by oxygen-saturated natural groundwater. The medium containing toluene was filter-sterilized groundwater, purged anoxic with $\mathrm{N}_{2}$ / $\mathrm{CO}_{2}$. The toluene concentration supplied to these columns was about $70 \mu \mathrm{M}$. The sampling followed the same protocols as described above.

Chemical and microbiological analyses

Samples for toluene measurement collected at the column inlets and outlets were transferred to close GC vials (Fig. 1) containing $\mathrm{NaOH}$ to terminate bacterial activity. Ethylbenzene was spiked prior to analysis as internal standard. We determined concentrations of toluene via headspace analysis by GC-MS following the protocols described in Anneser et al. (2008, 2010). Concentrations of nitrate were determined by ion chromatography (Dionex AS3500, Idstein, Germany).

Bacterial cell numbers in water and sediment samples were determined by flow cytometry (FCM). For water samples, $1 \mathrm{~mL}$ of sample was placed into an Eppendorf tube and fixed with $100 \mu \mathrm{L}$ of glutardialdehyde to a final concentration of $2.5 \%$. With sediment samples, a $0.5 \mathrm{~mL}$ aliquot was placed in a $2 \mathrm{~mL}$ Eppendorf tube and fixed with $1 \mathrm{~mL}$ of $2.5 \%$ glutardialdehyde solution. Fixed samples were stored at $4{ }^{\circ} \mathrm{C}$ until further analysis. Later, sediment samples were further processed as described in Bayer et al. (2016). We stained water samples as well as the samples containing bacteria detached from sediment in triplicates with SybrGreen I (1000x, Molecular Probes, Invitrogen Life Sciences, $1 \mu \mathrm{l} / \mathrm{mL}$ ) and determined cell densities in a Cytomics FC500 flow cytometer (Beckman Coulter System). The instrument settings for our experiment was: forward scatter $350 \mathrm{mV}$, sideward scatter $300-370 \mathrm{mV}$, bandpass filter $530 \mathrm{~nm} 500-580 \mathrm{mV}$ and green fluorescence, bandpass filter $610 \mathrm{~nm} 650 \mathrm{mV}$ and red fluorescence. The signal threshold was adjusted to $200 \mathrm{mV}$ for both scatters to minimize background noise (Bayer et al. 2016).

Modeling of batch experiments

\section{Direct utilization of toluene for growth}

In the standard model, we assume that the bacteria directly grow on the degradation of toluene. The electron acceptor is considered available in excess, and biomass decay is neglected. Then the standard Monod equations read as:

$\frac{d X}{d t}=\mu_{\max } \cdot \frac{c_{\text {tol }}}{c_{\text {tol }}+K_{\text {tol }}} \cdot X$

$\frac{d c_{t o l}}{d t}=-\frac{1}{Y} \frac{d X}{d t}$

in which $\mu_{\max }\left[\mathrm{s}^{-1}\right]$ is the maximum specific growth rate constant, $c_{t o l},[\mu \mathrm{M}]$ and $X$ [cells $\mathrm{L}^{-1}$ ] are the concentration of toluene and bacteria, respectively, whereas $K_{\text {tol }}[\mu \mathrm{M}]$ and $Y$ [cells $\left./ \mu \mathrm{mol}\right]$ are the halfsaturation concentration of toluene and the yield coefficient. This system of ordinary differential equation are subject to initial values of the two concentrations and was solved with the ode-solver ode 45 of Matlab, which is an explicit Runge-Kutta solver of fourth order.

\section{Consideration of a metabolite}

In a second model, we assume that the bacteria first transform toluene to a metabolite without growth, and then grow on the degradation of the metabolite. A suitable candidate metabolite is methyl-catechol. The modified equations read as:

$$
\begin{aligned}
& r_{t o l}=r_{t o l}^{\max } \cdot \frac{c_{t o l}}{c_{t o l}+K_{t o l}} \cdot X \\
& r_{m e t}=r_{m e t}^{m a x} \cdot \frac{c_{m e t}}{c_{m e t}+K_{m e t}} \cdot X \\
& \frac{d c_{t o l}}{d t}=-r_{t o l} \\
& \frac{d c_{m e t}}{d t}=r_{t o l}-r_{m e t} \\
& \frac{d X}{d t}=Y \cdot r_{m e t}
\end{aligned}
$$


in which $\left[\mu \mathrm{M} \mathrm{s}^{-1}\right]$ and $\left[\mu \mathrm{M} \mathrm{s}^{-1}\right]$ are the transformation rates of toluene and the metabolite, $\left[\mu \mathrm{mol}\right.$ cells ${ }^{-1}$ $\mathrm{s}^{-1}$ ] and [ $\mu \mathrm{mol}$ cells ${ }^{-1} \mathrm{~s}^{-1}$ ] are the corresponding maximum specific rates, and $c_{m e t},[\mu \mathrm{M}]$ is the concentration of the metabolite with the corresponding half-saturation concentration $K_{m e t}[\mu \mathrm{M}]$.

Reactive-transport modeling

\section{Governing equations}

We simulate microbial growth in the column systems coupled to one-dimensional reactive-transport with a numerical model that considers three mobile components, namely toluene (electron donor and carbon source), oxygen (electron acceptor), and suspended bacteria as well as the attached bacteria as immobile component. We model microbial growth of attached and suspended bacteria, depending on the simultaneous presence of toluene and oxygen, by dual Monod kinetics:

$r_{\text {growth }}^{\text {att }}=\mu_{\max } \cdot \frac{c_{t o l}}{c_{t o l}+K_{t o l}} \cdot \frac{c_{o x}}{c_{o x}+K_{o x}} \cdot X_{a t t}$

$r_{\text {growth }}^{\text {mob }}=\mu_{\max } \cdot \frac{c_{t o l}}{c_{t o l}+K_{t o l}} \cdot \frac{c_{o x}}{c_{o x}+K_{o x}} \cdot X_{m o b}$

in which $\mu_{\max }\left[\mathrm{s}^{-1}\right]$ is the maximum specific growth rate constant, $c_{t o l}, c_{o x}[\mu \mathrm{M}], X_{a t t}$ [cells $\left.\mathrm{L}_{\mathrm{sed}}^{-1}\right]$ and $X_{m o b}$ [cells $\mathrm{L}^{-1}$ ] are the concentration of toluene, oxygen, attached, and mobile bacteria, respectively, whereas $K_{t o l}$ and $K_{o x}[\mu \mathrm{M}]$ are the half-saturation concentrations of toluene and oxygen, respectively. The concentration of attached cells $\mathrm{X}_{\mathrm{att}}$ is expressed in number of cells per bulk volume of the sediments. Initially, we applied the same kinetic rate coefficients to the mobile and attached bacteria as expressed in Eqs. (8) and (9). However, due to the short residence time of mobile bacteria in the $1.6 \mathrm{~cm}$ long columns, growth of mobile bacteria was found to be insignificant, and was neglected in the further mathematical analysis.

One-dimensional transport of toluene and oxygen in the column system and their consumption due to growth of attached bacteria can be described by a system of coupled advection-dispersion-reaction equations (in which we have neglected sorption):

$$
\begin{aligned}
& \frac{\partial c_{t o l}}{\partial t}=-v \frac{\partial c_{t o l}}{\partial x}+D \frac{\partial^{2} c_{t o l}}{\partial x^{2}}-\frac{1}{Y}\left(r_{\text {growth }}^{\text {att }}+r_{\text {growth }}^{\text {mob }}\right) \\
& \frac{\partial c_{o x}}{\partial t}=-v \frac{\partial c_{o x}}{\partial x}+D \frac{\partial^{2} c_{o x}}{\partial x^{2}}-\frac{f_{o x}}{Y}\left(r_{\text {growth }}^{\text {att }}+r_{\text {growth }}^{\text {mob }}\right)
\end{aligned}
$$

with the linear transport velocity $v\left[\mathrm{~m} \mathrm{~s}^{-1}\right]$, the longitudinal dispersion coefficient $D\left[\mathrm{~m}^{2} \mathrm{~s}^{-1}\right]$, the microbial growth yield $Y$ [cells $\mu \mathrm{mol}_{\mathrm{tol}}^{-1}$ ] and the ratio of stoichiometric coefficients of oxygen and toluene $f_{\text {ox }}\left[\mu \mathrm{mol}_{\mathrm{tox}} \mu \mathrm{mol}_{\mathrm{tol}}^{-1}\right]$.

Results from the column experiments showed that the number of attached bacteria stopped increasing beyond a maximum value, indicating that there was a maximum carrying capacity of attached bacteria $\left(X_{a t t}^{\max }\right.$ [cells $\mathrm{L}_{\mathrm{sed}}^{-1}$ ) in the system. However, even when $X_{\text {att }}^{\max }$ was reached, the attached bacteria continued to replicate. In the model, the new-grown cells are released to the mobile aqueous phase and finally flushed out of the column. This release of new-grown cells from the sediment surface to the mobile aqueous phase has already been observed in earlier studies on microbial transport under growth conditions (e.g., Clement et al. 1997; Murphy et al. 1997; Yolcubal et al. 2002; Jordan et al. 2004; Mellage et al. 2015). We accounted for this process in the model by the dynamic detachment rate $r_{\text {daughter }}$ [cells $\mathrm{L}_{\mathrm{sed}}^{-1} \mathrm{~s}^{-1}$ ]:

$r_{\text {daughter }}=r_{\text {growth }}^{\text {att }} \cdot \frac{X_{\text {att }}}{X_{\text {att }}^{\max }}$

If $X_{\text {att }}^{\max }$ is not yet reached, new-grown cells partially stay attached and partially are released to the mobile aqueous phase. When the carrying capacity is approached, the term $X_{a t t} / X_{\text {att }}^{\max }$ approaches unity and all new-grown cells are released to the aqueous phase.

Attachment of suspended bacteria to the sediment surface is described by the modified first-order attachment rate $r_{\text {attach }}$ [cells $\mathrm{L}^{-1} \mathrm{~s}^{-1}$ ]:

$r_{\text {attach }}=k_{\text {att }} \cdot X_{\text {mob }} \cdot\left(1-\frac{X_{\text {att }}}{X_{\text {att }}^{\max }}\right)$

in which $k_{\text {att }}\left[\mathrm{s}^{-1}\right]$ is the first-order attachment rate coefficient and the term $\left(1-\frac{X_{\text {att }}}{X_{\text {att }}^{\text {max }}}\right)$ is introduced to account for the carrying capacity (Ding 2010). The rate of change of attached $X_{\text {att }}$ [cells $\mathrm{mL}_{\text {sed }}^{-1}$ and mobile $X_{m o b}\left[\right.$ cells $\mathrm{mL}^{-1}$ ] bacteria is described by: 
$\frac{\partial X_{\text {att }}}{\partial t}=r_{\text {growth }}^{\text {att }}+n \cdot r_{\text {attach }}-r_{\text {daughter }}$

$\frac{\partial X_{m o b}}{\partial t}=-v \frac{\partial X_{m o b}}{\partial x}+D \frac{\partial^{2} X_{m o b}}{\partial x^{2}}-r_{\text {attach }}+\frac{1}{n} r_{\text {daughter }}$

Note that the carrying capacity $X_{\text {att }}^{\max }$ is a prescribed model parameter that needs to be obtained by fitting the model to data. The model itself does not explain the mechanisms determining the carrying capacity.

\section{Numerical methods}

We discretized the coupled system of one-dimensional reactive-transport equations in space by the cellcentered Finite Volume Method with a spatial discretization of $\Delta x=0.5 \mathrm{~mm}$. We applied upwind differentiation of the advective term and set the dispersion coefficient to $1.95 \times 10^{-8} \mathrm{~m}^{2} \mathrm{~s}^{-1}$. The coupled system of spatially discretized reactivetransport equations was integrated in time by an implicit Euler method with adaptive time stepping and a maximum time-step size of $600 \mathrm{~s}$. The resulting system of coupled non-linear algebraic equations was linearized by the Newton-Raphson method, and the UMFPACK solver implemented in Matlab was used to solve the resulting system of linear equations. The code was written as a Matlab program.

\section{Results}

\section{Batch experiments}

Figure 2 shows measured and simulated concentrations of toluene and cell numbers in the batch experiments of aerobic toluene degradation with Pseudomonas putida F1. The lines show fitted model results, where the dashed lines represent the standard model, in which a given fraction of toluene is immediately used for biomass growth, and the solid lines represent the model with an intermediate metabolite (shown as dotted line) that can be further utilized for assimilation. It is obvious that the standard model fails at reproducing the data because the decrease in toluene concentrations precedes the increase in cell numbers. In the standard model, the fitted maximum specific growth rate $\mu_{\max }$ is
$4.25 \pm 0.24$ day $^{-1}$ and the fitted Monod constant $K_{\text {tol }}$ is $10.9 \pm 2.83 \mu \mathrm{M}$, with a yield coefficient of $Y=2.83 \times 10^{8}$ cells $\mathrm{mol}_{\mathrm{tol}}^{-1}$. In the model with the metabolite, the first reaction is considerably faster than the second one $\left(r_{\text {tol }}^{\max } / Y=24.06 \pm 0.01 / d\right.$ vs. $r_{\text {tol }}^{\max } /$ $Y=4.19 \pm 0.03 / d$, in which the scaling with the yield is chosen to make the numbers comparable to $\mu_{\max }$ of the standard model), and the Monod constant $K_{t o l}$ of $1.45 \pm 0.002 \mu \mathrm{M}$ is much better constrained.

In Figure S1 (Supporting Information) we show that the substrate carbon converted to biomass carbon over the entire experiment increased with the initial toluene concentration but plateaued for initial toluene concentrations of about $150 \mu \mathrm{M}$ and higher. At the end of all experiments, toluene was completely degraded. The finding of a maximum biomass concentration indicates decreasing carbon-assimilation efficiency with increasing carbon and electron-donor supply.

To fit the toluene and cell data for the batch experiments under nitrate-reducing conditions with Aromatoleum aromaticum EbN1, it was not necessary to consider a metabolite (see the model fit assuming direct utilization of toluene for growth in Figure S2 of the Supporting Information). The fit of the classical Monod-growth-model to all toluene and cell data revealed a $\mu_{\max }$ of 0.35 day $^{-1}, K_{\text {tol }}=21.7 \mu \mathrm{M}$, and $Y=1.38 \times 10^{8}$ cells $\mu \mathrm{mol}_{\mathrm{tol}}^{-1}$. The maximum specific growth rate of the aerobe $P$. putida $\mathrm{F} 1$ was about 10 times higher than that of the denitrifier A. aromaticum $\mathrm{EbN} 1$, and $K_{t o l}$ was 15 times larger for the denitrifyer.

Sediment column experiments

We performed experiments with different toluene concentrations in the inflow and different flow velocities with $P$. putida F1, A. aromaticum EbN1, and a natural aquifer microbial community. Table 1 summarizes key results of the individual experiments with regard to toluene degradation, oxygen consumption, and microbial growth.

\section{Toluene degradation}

The reduction in toluene concentration $(\Delta \mathrm{Tol})$ in the individual column experiments with $P$. putida F1 (Exp A to Exp C) showed a linear decrease with increasing flow velocity at identical inflow concentration (Table 1, Fig. 3b, c). The total toluene transformation within $192 \mathrm{~h}$ ranged from $12.2 \mu \mathrm{mol}$ in Exp A 

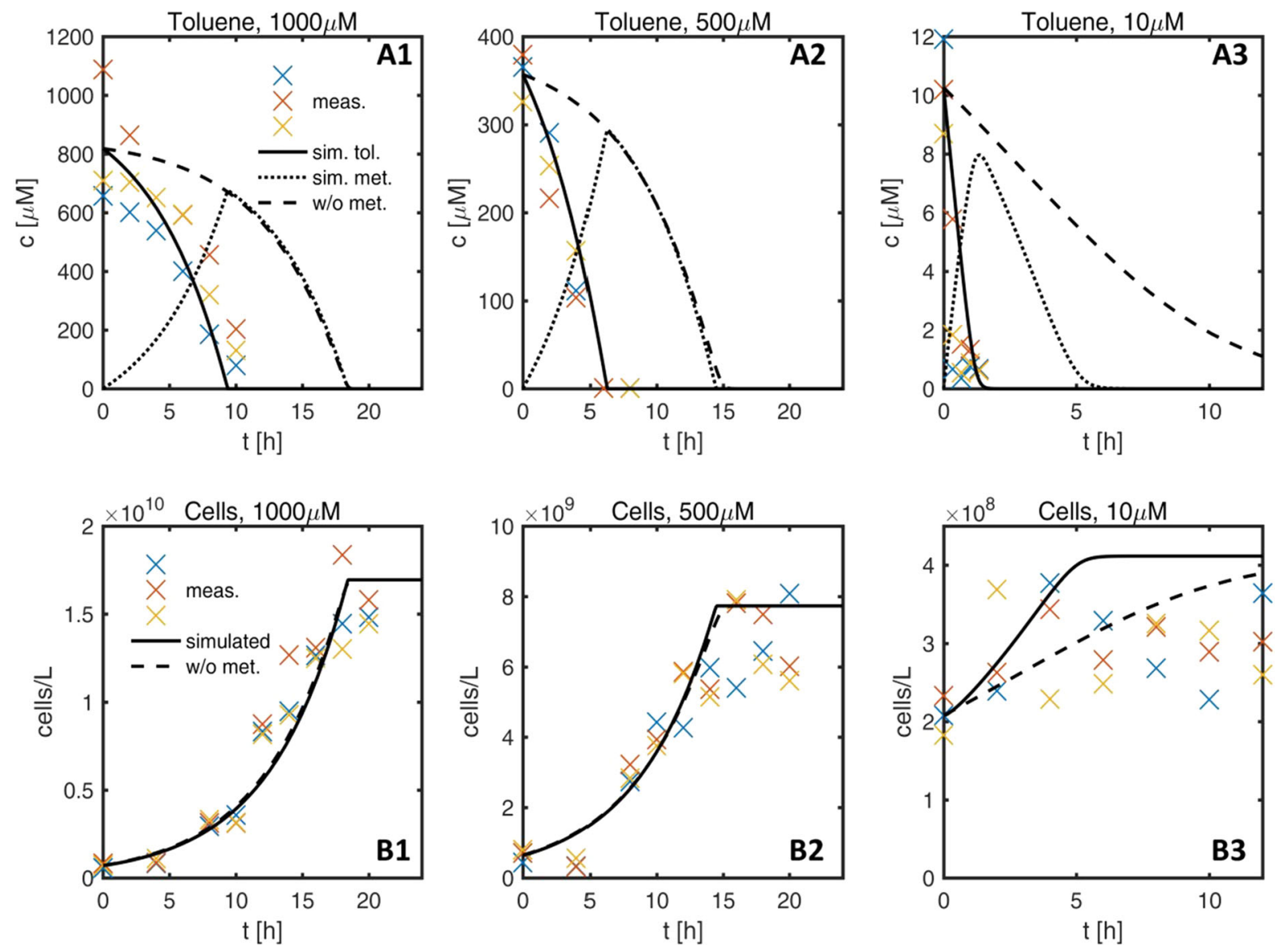

Fig. 2 Measured and simulated toluene concentrations and bacterial growth of $P$. putida F1 over the course of batch experiments with different substrate starting concentrations. The color coded data points represent measured values of toluene and cells $/ \mathrm{ml}$, respectively, from batch triplicates. Two

scenarios were considered, (1) with the formation of the central metabolite 3-methyl catechol (solid back lines-simulated toluene, dotted back lines-simulated metabolite), and (2) without metabolite (black dashed lines)

$\left(\mathrm{v}=0.6 \mathrm{~m} \mathrm{day}{ }^{-1}\right)$ to $53.6 \mu \mathrm{mol}$ in $\operatorname{Exp} \mathrm{C}$ $\left(\mathrm{v}=3.6 \mathrm{~m} \mathrm{day}^{-1}\right)$ exhibiting a positive trend, i.e. an increase with increasing flow velocity and thus increasing toluene mass flux. With respect to the toluene removal efficiency, the experiment with the lowest flow velocity, Exp A, showed 100\% toluene removal followed by Exp B and C. At the highest flow velocity, only $69 \%$ of the toluene could be degraded aerobically by $P$. putida (Table 1 ). With regard to the inflow concentration, $\Delta$ Tol increased with increasing $\mathrm{C}_{\mathrm{Tol}}$. However, at the highest toluene concentration in the inflow $(100 \mu \mathrm{M}$; Exp E) the data clearly hint at an oxygen limitation and degradation efficiency dropped to $59 \%$ (Fig. 4; Table 1). After establishment of full biodegradation activity, also experiments $\mathrm{D}(P$. putida at lower source concentration) and $\mathrm{G}$ (natural aerobic consortium) revealed $100 \%$ toluene removal efficiency (Table 1; Fig. 3c). Further relationships between toluene source concentration, flow velocity, and biodegradation efficiency are depicted in Fig. 3a-c.

Figure 4 exemplarily depicts the time series of concentrations and cell numbers for one set of experimental conditions (Exp. E: P. putida, $\left.c_{\text {tol }}=100 \mu \mathrm{M}, v=1.8 \mathrm{~m} \mathrm{day}^{-1}\right)$. As can be seen, the concentration of toluene in the column outflow as well as the oxygen concentration within the sediment column immediately started to decline and both leveled off after 1-2 days at concentrations of approximately $45 \mu \mathrm{M}$ toluene and $<0.2 \mu \mathrm{M}$ dissolved oxygen, respectively (Fig. 4). No differences in the oxygen values were found between the bottom, 
Table 1 Comparison of column experiments with P. putida F1, A. aromaticum EbN1, and a natural toluene degrading community at different flow rates and toluene source concentrations

\begin{tabular}{|c|c|c|c|c|c|c|c|c|c|c|}
\hline Exp & $C_{T o l}^{i n}(\mu \mathrm{M})$ & $v$ (m/day) & $\begin{array}{l}\Delta \mathrm{Tol} \\
(\mu \mathrm{M})\end{array}$ & $\begin{array}{l}\Delta \mathrm{Tol} \\
(\%)\end{array}$ & $\begin{array}{l}\Delta \mathrm{O}_{2} \\
(\mu \mathrm{M})\end{array}$ & 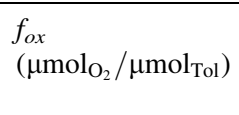 & $\begin{array}{l}\text { New cells } \\
\left(\times 10^{8}\right. \\
\text { cells })\end{array}$ & $\begin{array}{l}\text { Cells } \\
\text { flushed out } \\
(\%)\end{array}$ & $\begin{array}{l}\text { Yield }\left(\times 10^{7}\right. \\
\left.\text { cells } / \mu \mathrm{mol}{ }_{\mathrm{Tol}}\right)\end{array}$ & $\begin{array}{l}\text { Cells } \\
\text { attached } \\
(\%)\end{array}$ \\
\hline
\end{tabular}

\section{P. putida F1}

$\begin{array}{ccc}\text { A } & 70(66.9) & 0.6 \\ \text { B } & 70(65) & 1.8 \\ \text { C } & 70(73.5) & 3.6 \\ \text { D } & 30(26.3) & 1.8 \\ \text { E } & 100(113) & 1.8\end{array}$

$\begin{array}{lrll}66.9 & 100 & 207 & 3.1 \\ 59.6 & 92 & 203 & 3.4 \\ 51 & 69 & 261 & 5.1 \\ 26.3 & 100 & 104 & 3.95 \\ 67.2 & 59 & 247 & 3.7\end{array}$

4.4
14
28
6.6
53

70
76
79
72
93

$\begin{array}{ll}3.6 & 99 \\ 4.0 & 99 \\ 5.3 & 99 \\ 5.8 & 99 \\ 11.7 & 98\end{array}$

A. aromaticum EbN1

$$
\text { F } \quad 70(85.4) \quad 1.8
$$

10

20

3.0

99

Natural microbial community

$$
\text { G } \quad 70(73.1) \quad 1.8
$$

11

50

3.5

99

$C_{T o l}^{i n}$ : toluene concentration in the inflow (target concentrations are listed first, actual concentrations given in brackets), $v$ : velocity, $\Delta$ Tol: difference in toluene concentration between in- and outflow, $\Delta \mathrm{O}_{2}$ : difference in oxygen concentration between in- and outflow, $f_{\text {ox }}$ : stoichiometric ratio between oxygen and toluene, New Cells: increase in cell numbers

Fig. 3 Influence of toluene inlet concentration (solid arrows) and flow velocity (dashed arrows) on biodegradation, growth and yield, as well as the distribution of bacterial cells on the sediment and in porewater

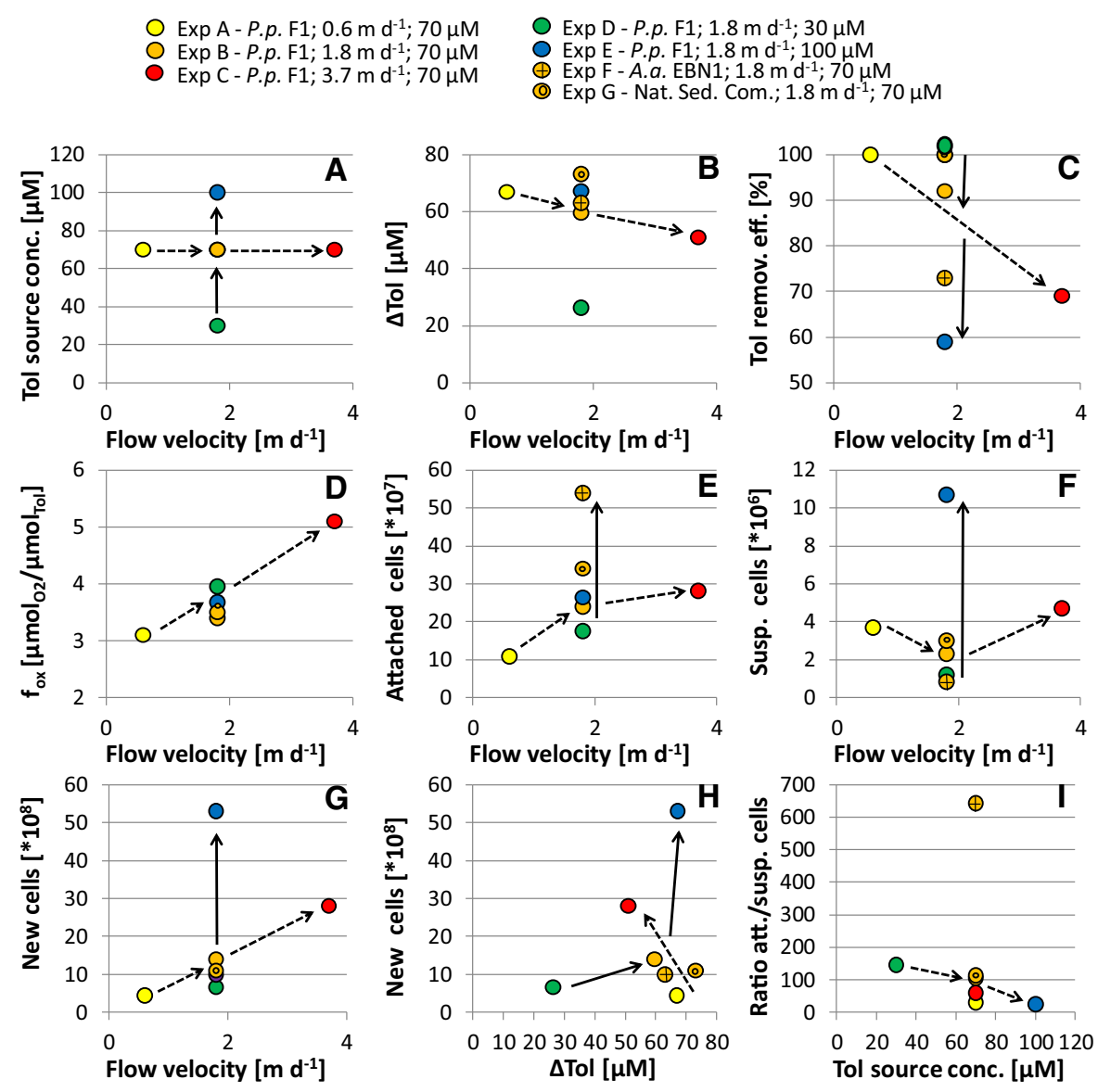


Fig. 4 Aerobic toluene degradation and growth of $P$. putida $\mathrm{F} 1$ at a continuous source concentration of $100 \mu \mathrm{M}$ and a flow velocity of $1.8 \mathrm{~m} \mathrm{day}^{-1}$ (Exp E). Values are means of triplicate measurements \pm SD
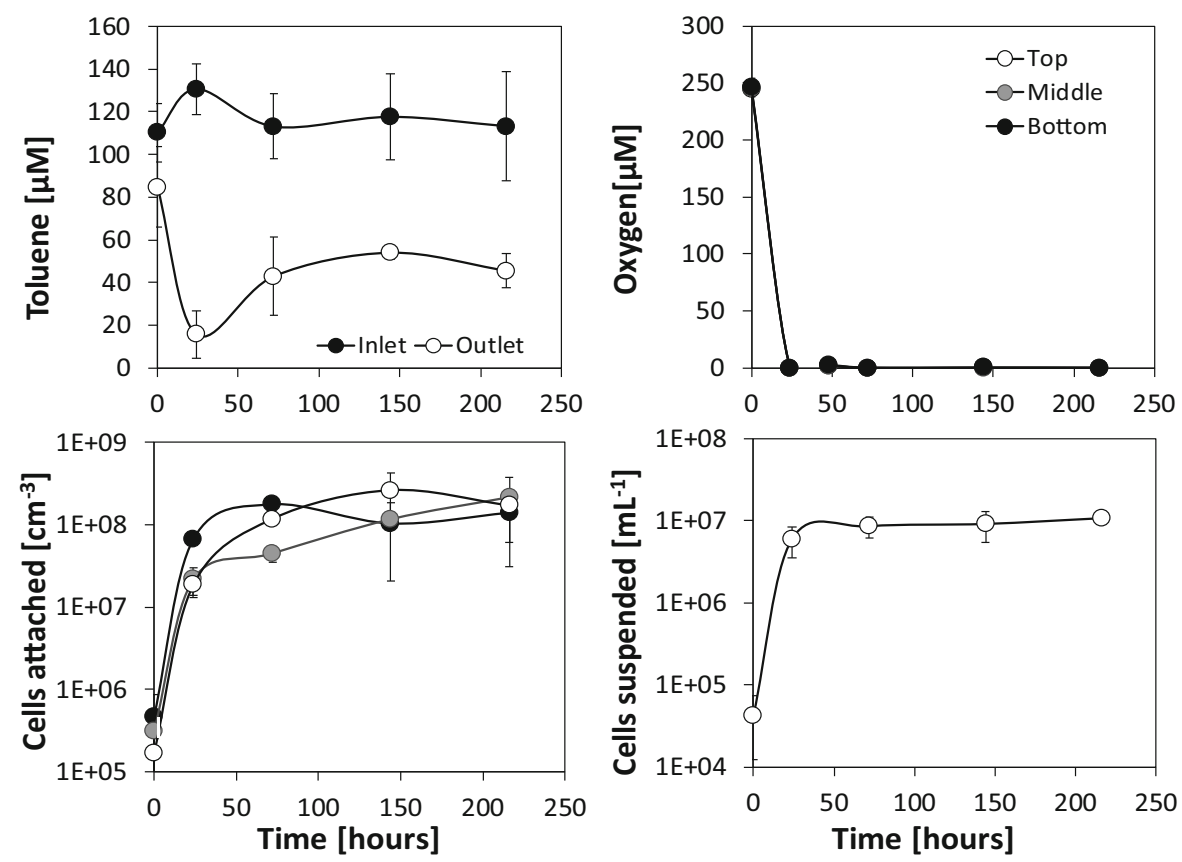

middle, and top column observation points indicating that oxygen was readily consumed in the bottom (inflow) part of the column. Experiments at lower inflow concentrations of toluene and varying flow velocities exhibited similar patterns (see Supplementary Information, Figs. S3-S6).

In the column experiment $\mathrm{F}$, which is similar to that depicted in Fig. 4, toluene degradation was examined under nitrate reducing conditions by the strain $A$. aromaticum $\mathrm{EbN} 1$. Here, the bacterial population took 3 days to establish the full toluene degradation capacity, which was considerably slower than the aerobic culture $P$. putida. We chose a nitrate concentration of $500 \mu \mathrm{M}$ because this concentration would be sufficient for the complete transformation of the foreseen $70 \mu \mathrm{M}$ toluene in a perfectly mixed solution. Unfortunately, the actual inflow concentration of toluene was about $80 \mu \mathrm{M}$ and thus a bit higher than intended. In fact, the columns outflow still contained about $20 \mu \mathrm{M}$ of toluene, pointing at a nitrate limitation under the flow-through conditions in the mini sediment column (Fig. S7).

The natural microbial sediment community fed by oxic groundwater containing $70 \mu \mathrm{M}$ toluene (Exp. G) was able to readily degrade toluene, albeit the maximum degradation efficiency was reached much later than with the specific degrader strains applied, i.e. after 6 days compared to 1-2 days with the $P$. putida $\mathrm{F} 1$ and 3 days with $A$. aromaticum $\mathrm{EbN} 1$. After establishment of quasi steady-state conditions in the sediment columns, the change of toluene concentration between the in- and outlet under similar experimental conditions $\left(c_{t o l}=70 \mu \mathrm{M}, v=1.8 \mathrm{~m} \mathrm{day}^{-1}\right)$ by $P$. putida $\mathrm{F} 1(59.6 \mu \mathrm{M})$, A. aromaticum EbN1 $(63.1 \mu \mathrm{M})$ and the natural microbial community $(73.1 \mu \mathrm{M})$ were in a similar range.

Based on toluene and oxygen measurements $\left(\Delta \mathrm{O}_{2}\right.$ and $\Delta \mathrm{Tol}$ at fully established biodegradation activity; Table 1) conducted for the column experiments with $P$. putida $\mathrm{F} 1$ and the natural aquifer community, we calculated the empirical stoichiometric ratio $f_{\text {ox }}$ between oxygen consumption and toluene degradation, as well as bacterial growth. The $f_{o x}$-values obtained for the different experiments fell in the range of 3.1-5.1 $\mu \mathrm{M}_{\mathrm{Tol}} \mu \mathrm{M}_{\mathrm{O}_{2}}^{-1}$. We found the highest stoichiometric ratio with the highest flow velocity (Exp C) and thus the highest toluene mass flux. $f_{\text {ox }}$ decreased together with the flow velocity (Fig. 3d). No pronounced differences in $f_{o x}$ nor a consistent trend were observed with varying inflow concentration (Fig. 3d). In the experiment with the natural aquifer community a similar $f_{o x}$-value (3.5) was found as with P. putida F1 under comparable environmental conditions (Table 1). 
A high stoichiometric ratio $f_{\text {ox }}$ translates into low carbon biomass yield. The highest yield under quasi steady-state conditions was thus with the lowest toluene mass flux. However, dissecting the column experiments into an initial phase of rapid cell production and the subsequent phase at quasi-steady state revealed a very dynamic biomass yield. In almost all experiments, carbon assimilation was extremely high in the initial phase of growth and then decreased within two, maximal 3 days to a lower constant value when the carrying capacity for the cell density was reached (see the carbon assimilation efficiency in Fig. S8).

Due to technical problems, nitrate concentrations could not be measured in the column experiment $\mathrm{F}$ with A. aromaticum EbN1. Therefore, we could not evaluate the stoichiometry between toluene degradation and nitrate consumption under nitrate-reducing conditions.

\section{Microbial growth}

In all column experiments the number of bacterial cells attached to the sediment substantially increased within the first 1-3 days. As exemplarily depicted in Fig. 4 , the number of attached cells per volume sediment, here at an inflow concentration of $100 \mu \mathrm{M}$ and a flow velocity of $1.8 \mathrm{~m} \mathrm{day}^{-1}$, increased by more than three orders of magnitude within $72 \mathrm{~h}$ and then stayed rather constant for the remaining time of the experiment. The maximum density of attached cells reached $2.6 \times 10^{8} \pm 1.6 \times 10^{8}$ cells $\mathrm{mL}_{\text {sed }}^{-1}$. The number of cells suspended in the pore-water collected at the column outflow also increased by two orders of magnitude reaching a constant value of about $1 \times 10^{7}$ cells $\mathrm{mL}^{-1}$ already after $48 \mathrm{~h}$. This constant outwash of $1 \times 10^{7}$ cells $\mathrm{mL}^{-1}$ following day two, pointed at an actively growing attached bacterial population, releasing its daughter cells into the mobile water phase. Since $99 \%$ of the cells per sediment volume were found attached to the sediment surface (see Table 1) and the water residence time in the columns was considerably short (12.7 min), toluene degradation and microbial growth could be fully attributed to the attached populations in the column system. However, over the entire phase of the experiment $(192 \mathrm{~h}), 97 \%$ of all newly produced cells were transported out the columns in experiment $\mathrm{E}$.
We observed similar patterns for the other column experiments (Table 1). For P. putida F1, the final number of cells associated to the sediment showed a positive trend with increasing flow velocity as well as with increasing toluene inlet concentration (Fig. 3e). The highest abundance of attached cells was obtained in the experiments with the denitrifyer A. aromaticum (Fig. 3e). In the pore-water, patterns of cell numbers were less clear. While, increasing toluene concentrations in the inlet pushed the cell numbers in the porewater from $1.2 \times 10^{6}$ cells $\mathrm{mL}^{-1}$ in $\operatorname{Exp} \mathrm{D}(30 \mu \mathrm{M})$ to $1 \times 10^{7}$ cells $\mathrm{mL}^{-1}$ in $\operatorname{Exp} \mathrm{E}(100 \mu \mathrm{M})$, we could not observe a conclusive dependence of cell-numbers in the pore water and flow velocity (Fig. 3f). The ratio of attached to suspended cells ranged from 14 to 643, with the highest ratio for the denitrifyer A. aromaticum (Fig. 3i). For the aerobic strain P. putida F1 and with the natural aerobic consortium, we observed a lower ratio of attached to suspended cells (Fig. 3i).

Similar to the maximum total cell numbers observed in the pore-water and attached to the sediment, the number of newly grown cells, as determined by direct cell counts, systematically increased with the increase of toluene concentration in the inflow as well as with the flow velocity (Table 1; Fig. 3g, h). Consequently, we observed a similar trend for the microbial growth yield $Y$ [cells $\mu \mathrm{mol}_{\text {tol }}^{-1}$ ].

The estimated growth yield for the column experiments with $A$. aromaticum EbN1 under denitrifying conditions and the natural community, with values of $3.0 \times 10^{7}$ and $3.5 \times 10^{7}$ cells $\mu \mathrm{mol}_{\text {tol }}^{-1}$, respectively, were in a similar range as for $P$. putida $\mathrm{F} 1$ (of $\left.4.0 \times 10^{7}\right)$ under similar experimental conditions (70 $\mu \mathrm{M}$ toluene, $v=1.8 \mathrm{~m} \mathrm{day}^{-1}$ ) (Table 2 and Fig. $3 g, h)$.

Even though a large fraction of the newly grown cells in the flow-through experiments conducted with $P$. putida F1 were flushed out of the column over time (60-93\%), at any given time point the majority of cells per volume of water-saturated sediment was found to be attached to the sediment surface, regardless of the experiment ( $\geq 98 \%$, Table 1 ). The experiment using the natural aquifer community showed a considerably lower percentage of washed-out cells (50\%), and the experiment using A. aromaticum $\mathrm{EbN} 1$ had the lowest percentage of washed-out cells (20\%, Table 1). While the measurements of attached cells showed a distinct gradient in cell numbers along the length of the column in Exp B, with the highest cell numbers in the 
Table 2 Model parameters

\begin{tabular}{|c|c|c|c|c|c|}
\hline Parameter & Exp A & Exp B & Exp C & Exp F & $\operatorname{Exp} G$ \\
\hline$\mu_{\max }\left(1 \mathrm{day}^{-1}\right)$ & 4.5 & 4.5 & 3.0 & 2.0 & 0.5 \\
\hline$K_{t o l}\left(\mu \mathrm{mol} \mathrm{L}{ }^{-1}\right)$ & 1.1 & 1.1 & 1.1 & 21.7 & 1.1 \\
\hline$K_{o x}\left(\mu \mathrm{mol} \mathrm{L} \mathrm{L}^{-1}\right)$ & $10^{\mathrm{a}}$ & $10^{\mathrm{a}}$ & $10^{\mathrm{a}}$ & - & $10^{\mathrm{a}}$ \\
\hline$f_{o x}\left(\mu \mathrm{mol}_{\mathrm{O}_{2}} / \mu \mathrm{mol}_{\mathrm{Tol}}\right)$ & 2.6 & 4.0 & 4.9 & - & 3.7 \\
\hline$k_{\text {att }}\left(1 \mathrm{day}^{-1}\right)$ & 50 & 50 & 50 & 50 & 50 \\
\hline (cells $\mathrm{mL}_{\mathrm{Sed}}^{-1}$ ) & $0.9 \times 10^{8}$ & $2.0 \times 10^{8}$ & $2.7 \times 10^{8}$ & $5.4 \times 10^{8}$ & $3.4 \times 10^{8}$ \\
\hline$Y\left(\right.$ cells $\left.\mu \mathrm{mol}_{\mathrm{Tol}}^{-1}\right)$ & $3.6 \times 10^{7}$ & $4.0 \times 10^{7}$ & $5.3 \times 10^{7}$ & $3.0 \times 10^{8}$ & $3.5 \times 10^{7}$ \\
\hline
\end{tabular}

Parameters given in bold were fitting parameters. The maximum number of attached cells $X_{\text {att }}^{\max }$ was set to be the highest number of cells/ml obtained from sediment analysis in each experiment. The yield coefficient $\mathrm{Y}$ in the model was calculated from the column data by comparing the number of newly formed cells to the amount of degraded toluene. $\mathrm{K}_{\mathrm{tol}}$ was taken from the preceding batch experiments, and $\mathrm{K}_{\mathrm{ox}}$ was obtained from the literature

${ }^{a}$ Bauer et al. (2009)

bottom (inlet) part of the column, no pronounced spatial gradient along the bottom, middle, and top parts of the columns was found in the other experiments (Figs. S3-S8).

We estimated the growth yield in our experiments in two ways: First, by converting the $f_{\text {ox }}$-values (see above) to yield coefficients, and second by comparing the amount of newly grown cells to the toluene mass degraded. The range of $f_{o x}$-values between 2.6 and $5.5 \mu \mathrm{mol}_{\mathrm{Tol}} \mu \mathrm{mol}_{\mathrm{O}_{2}}^{-1}$ (Table 1), indicates carbon assimilation efficiencies of $0.39-0.72$. Summing up all newly formed cells within the individual experiments led to similar carbon assimilation efficiencies of 0.35-0.7. The bacterial cell size of $P$. putida F1, sporadically determined via fluorescence microscopy, was found to be rather constant in the column experiments, with an average length of $1.6 \mu \mathrm{m}$ and an average width of $0.8 \mu \mathrm{m}$. This corresponds to a biovolume of roughly $0.5 \mu \mathrm{m}^{3}$ per cell. Consequently, a mean cell carbon content of $130 \mathrm{fg}$ was used for the conversion of cell numbers into cell carbon.

\section{Reactive-transport modeling}

Figure 5 depicts concentration and cell-count time series of the column experiments A-C, performed with $P$. putida $\mathrm{F} 1$ at different flow velocities, as well as the experiment performed with the denitrifier $A$. aromaticum EbN1 (Exp F) and the natural microbial community (Exp G), together with the corresponding time series obtained by reactive-transport simulations.
Table 2 lists the individual model parameters. The maximum specific growth rate $\mu_{\max }$, the stoichiometric coefficient for oxygen consumption $f_{o x}$, and the attachment rate coefficient $k_{\text {att }}$ were fitting parameters. All remaining parameters were either calculated from the batch and column data prior to the simulations or taken from the literature.

The model reproduces the observed breakthrough curves of toluene and suspended cells at the column outlet, as well as the temporal evolution of the number of attached cells in the bottom, middle, and top parts of the columns very well, with exception of dissolved oxygen. The largest discrepancy between experimental and simulation results was found for the experiment with the natural microbial community (Exp G), for which the measurements indicated complete oxygen depletion already in the bottom (inflow) part of the column, whereas the simulation results showed a continuous gradient in oxygen concentrations along the length of the column.

While the concentration of suspended cells in the outflowing water was in the same range in all experiments conducted with $P$. putida $\mathrm{F} 1$ at a toluene concentration of $70 \mu \mathrm{M}$, the flux of cells leaving the column was increasing with higher flow rates. The leveling off in the number of attached cells at a maximum value is enforced in the model by introduction of the maximum number of attached cells $X_{\text {att }}^{\max }$ in Eqs. (12) and (13). Without this term, we would have achieved higher biomass concentrations, particularly close to the column inlet. The model also captures the continuous outflow of 2 to $4 \times 10^{6}$ cells $\mathrm{mL}^{-1}$ in all 

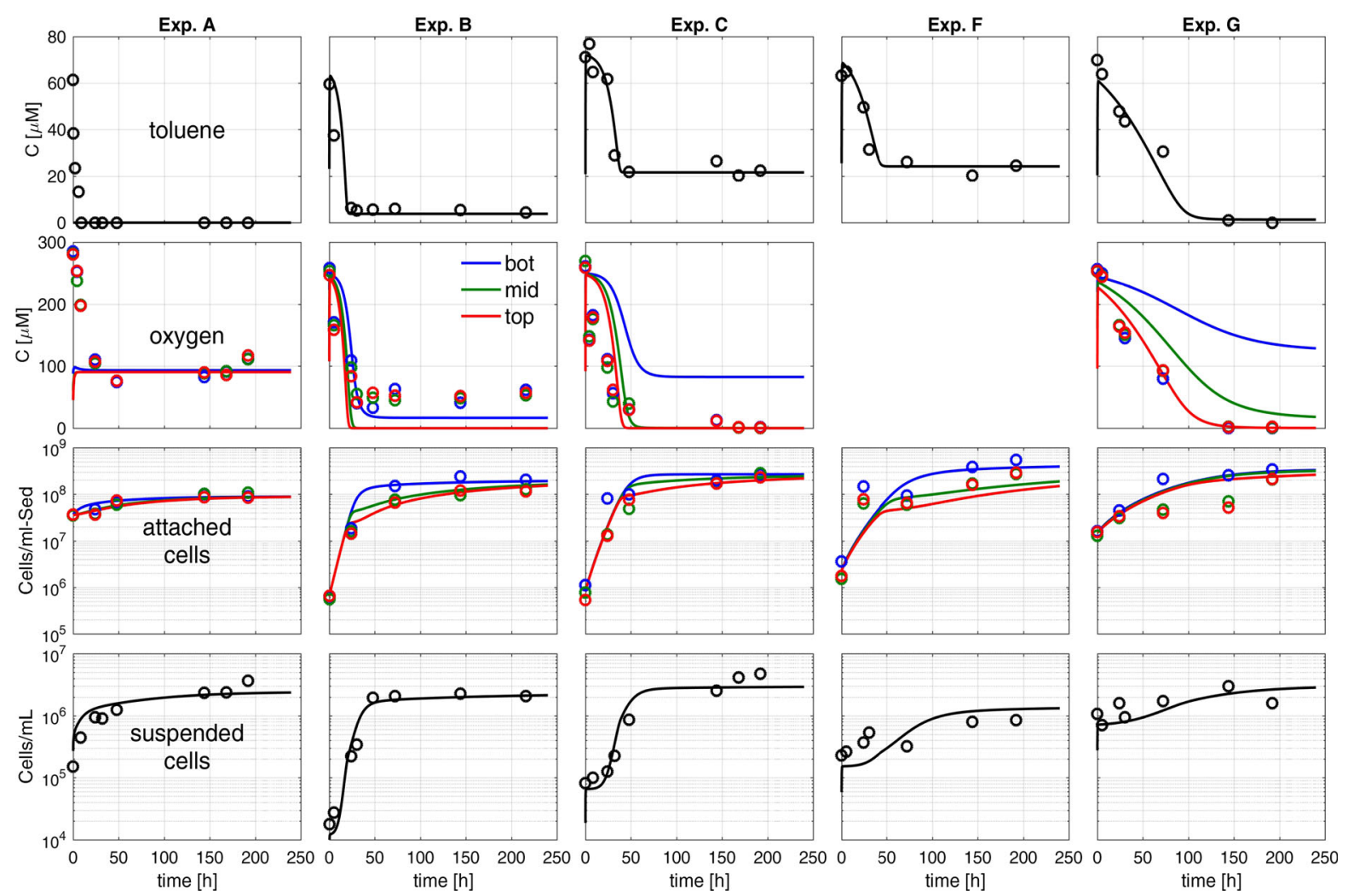

Fig. 5 Comparison of the experimental data and simulation results for selected column experiments; bot column bottom (close to inlet), mid middle part of the column, top top part of the column (close to outlet)

experiments conducted with P. putida F1 and $70 \mu \mathrm{M}$ toluene well because it simulates the release of newgrown cells from the sediment (immobile phase) to the mobile aqueous phase by the dynamic growth-depended detachment rate $r_{\text {daughter }}$ (Eq. 12). This term balances biomass growth once the carrying capacity of the system for attached cells is reached.

Because the vast majority of bacteria, and hence biodegradation activity per volume water saturated sediment, was located at the sediment surfaces rather than in the aqueous phase (see Table 1), toluene degradation in the columns could be almost exclusively attributed to the attached bacterial populations. Moreover, additional simulations, in which growth of suspended bacteria was accounted for, revealed the same results as simulations in which growth of suspended bacteria was neglected (data not shown). The concentration profiles of toluene and attached cells could even be reproduced without explicit consideration of mobile cells, if a logistic growthterm of the form $\left(1-\frac{X_{a t t}}{X_{\text {att }}^{\text {alx }}}\right)$ was applied to the microbial growth rate, but not to the rates of toluene and oxygen consumption. While suspended bacteria were found to be unimportant for toluene degradation, between 20\% (Exp F) and 93\% (Exp E) of the newly grown cells were flushed out of the columns over time (Table 1).

The remaining toluene concentration at the outlet of the columns inoculated with $P$. putida $\mathrm{F} 1$ increased with the flow rate from Exp B. $\left(1.8 \mathrm{~m} \mathrm{day}^{-1}\right)$ to $\operatorname{Exp~C}$ $\left(3.6 \mathrm{~m} \mathrm{day}^{-1}\right)$, and the initial drop in toluene concentration was faster for Exp B than for Exp C. This is also captured by the fitted values of $\mu_{\max }$ (Table 2). While the same value was applicable for Exp B and the batch experiments, a slightly lower one had to be chosen to match the results of Exp. C, which is the experiment with the higher flow velocity.

The fitted maximum specific growth rate $\mu_{\max }$ of 0.5 day $^{-1}$ in the experiment with the natural microbial community is almost one order of magnitude smaller than the value estimated for the experiment with $P$. putida $\mathrm{F} 1$ at the same flow velocity $\left(\mu_{\max }=4.5\right.$ 
Fig. 6 Simulated spatial profiles for toluene, oxygen and attached cell concentrations for Exp B-C, and $\mathrm{G}$ after steady state has been reached $(\mathrm{t}=200 \mathrm{~h})$
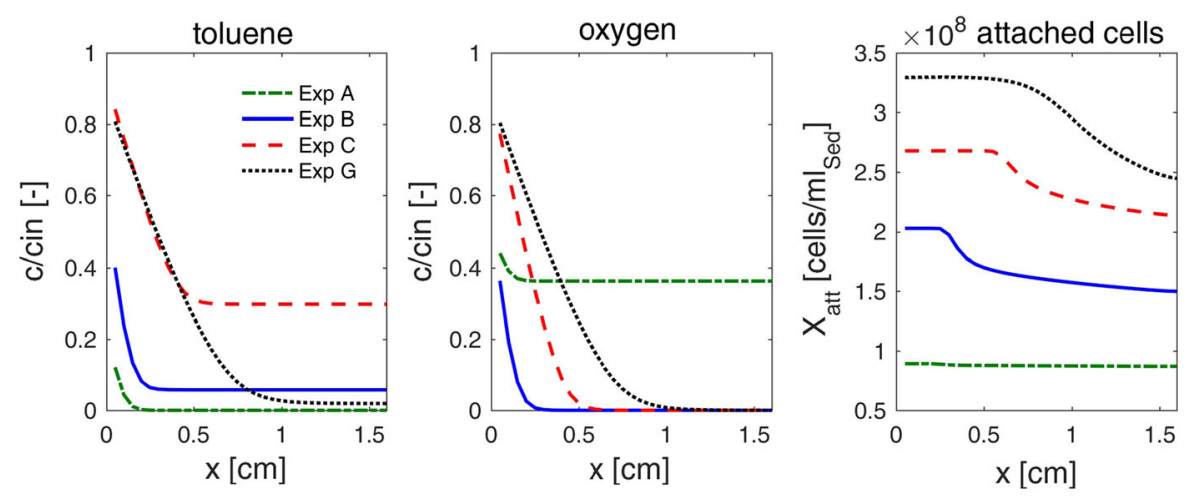

the experiment, when oxygen was still available along the entire column.

Figure 6 depicts simulated spatial profiles of toluene, oxygen, and attached cells in the sediment columns for the experiments A-C ( $P$. putida $\mathrm{F} 1$ with $\left.C_{T o l}^{i n}=70 \mu \mathrm{M}\right)$, and experiment $\mathrm{G}$, conducted with the natural microbial community, after steady state has been reached $(t=200 \mathrm{~h}$ ). The model predicts a rapid decrease in toluene concentrations with travel distance, and the complete consumption of oxygen within the first centimeter for all experiments. This matches the fact that no differences in oxygen profiles could be observed between the three locations in the columns.

\section{Discussion}

Batch versus flow-through experiments

Microbial growth observed in batch tests using different initial toluene concentrations exhibited clear first-order degradation kinetics. Model fits of the batch tests showed a maximum specific growth rate $\mu_{\max }$ of 4.5 day $^{-1}$ for P. putida F1, which is somewhat smaller than literature values ranging from 12 to $21 \mathrm{day}^{-1}$ (Abuhamed et al. 2004; Alagappan and Cowan 2004; Reardon et al. 2000). In the batch experiments with $P$. putida F1 at higher concentrations, we observed that biomass growth continued even after toluene had already completely been consumed (see Fig. 2). In these instances the standard Monod growth model could not simultaneously explain the toluene and cell data. Yu et al. (2001) observed a similar pattern and provided evidence that the buildup and further breakdown of 3-methylcatechol, a central intermediate in toluene degradation by $P$. putida F1, was responsible 
for the observed mismatch. Considering a central intermediate, the chemical nature of which has not been identified in the current experiments, we could fit the batch experiments involving $P$. putida much better (see solid lines in Fig. 2). For A. aromaticum EbN1, the denitrifying strain, ten times lower maximum specific growth rates were found with $\mu_{\max }$ values of $0.3 \mathrm{day}^{-1}$. Here, literature values range between 2.2 and 2.6 day $^{-1}$ (Evans et al. 1991; Jorgensen et al. 1995).

While the maximum specific growth rates of $P$. putida $\mathrm{F} 1$ in the batch and flow-through systems were similar, the mean growth rates differed. In batch systems with initial concentrations of $50 \mu \mathrm{M}$ toluene or more, the mean growth rates were consistently higher than in column experiments with inflow concentrations of $70 \mu \mathrm{M}$ of toluene. However, in batch systems the bacteria are exposed to a limited mass of toluene, they grow quickly, consume the toluene and stop growing because they run out of substrate. In the flow-through systems, by contrast, the bacteria exhibit a permanent supply of the substrate. They grow until they approach the carrying capacity, when they start to release the new grown cells. That is, the control of biomass growth considerably differs among the two systems.

The picture was different for the denitrifying strain A. aromaticum EbN1. Here the growth rates were much higher (factor of 20) in the flow-through experiments. The reason for that is not fully clear. However, there are strong indications from the sediment-column experiments that A. aromaticum EbN1 prefers to grow attached to surfaces as seen from the ratio between attached versus suspended cells (Fig. 3i) and the very different growth rates of suspended and attached cells in the sediment columns (Fig. S10). Without sediments to attach to, $A$. aromaticum EbN1 obviously experiences less favorable growth conditions.

In terms of yield, $P$. putida F1 was more efficient converting toluene carbon into biomass carbon at lower concentrations in the flow-through sediment columns than in the batch systems. At an initial toluene concentration of $10 \mu \mathrm{M}$ no significant increase in cell numbers could be detected in the batch experiment. As a consequence, at low substrate concentrations, substrate turnover fuels cell maintenance and energy production rather than growth (Egli 2010). At concentrations $>100 \mu \mathrm{M}$, carbon assimilation efficiencies became pronounced with values between 0.38 and 0.55 in the batch experiments (Figs. S1 and S2). The latter values are well comparable to the flow-through systems (0.43-0.7).

The yield of A. aromaticum EbN1 was comparable to $P$. putida in the batch system. Since there was only one column experiment with $A$. aromaticum $\mathrm{EbN} 1$ and we lacked nitrate data for the columns, a direct comparison between batch and flow-through sediment microcosms was not valid.

Column experiments: impact of flow velocity and inflow concentration

\section{Toluene degradation and bacterial growth}

In all column experiments, the difference between the inlet and outlet concentrations of toluene $(\Delta \mathrm{Tol})$ initially increased and then reached a steady value, which we denote the maximum degradation efficiency. While steady overall turnover was eventually reached in all column experiments, the time needed to approach the steady value differed between the bacteria involved. Pseudomonas putida F1 generally reached maximum degradation efficiency within 1-2 days, A. aromaticum EbN1 needed 3 days, and the natural microbial community was the slowest with a maximum degradation efficiency approached after 6 days. We may explain this by biodegradation being related to the amount of active biomass (specific degrader) and the growth rate being related to the energy gained. In the batch experiments, the denitrifying strain A. aromaticum EbN1 had a much smaller maximum specific growth rate $\mu_{\max }$ than the aerobic strain $P$. putida F1. The difference was smaller in the case of the column experiments. As depicted in Table 2 and Fig. S10, proliferation of attached $A$. aromaticum EbN1 cells is in the same range as that of $P$. putida F1 (see below). The natural microbial community, by contrast to the specific cultures, consisted of probably thousands of different strains, with only a small fraction readily capable of aerobic toluene degradation and related growth (Castillo and Ramos 2007; Okpokwasili and Nweke 2005; Vecht et al. 1988).

While the total amount of degraded toluene increased with the flow velocity, toluene removal efficiency, i.e. the percentage of the injected toluene mass which was degraded while being transported 
through the column, decreased. A similar pattern was observed for the maximum specific growth rate $\mu_{\max }$ (see Tables 1 and 2, Fig. 2). An explanation is that the mass-transfer of toluene and oxygen/nitrate from the pore-water to the interior of attached bacteria exerts a stronger control on reactive turnover at higher flow velocities because the characteristic time scale of mass-transfer into the cells is independent of velocity whereas the characteristic time of advection is inversely proportional to velocity. Mass transfer limitations were put forward as explanation for decreased degradation rates in porous media by numerous studies (e.g., Dykaar and Kitanidis 1996; Simoni et al. 2001; Hesse et al. 2009). At a fixed flow velocity, increasing the toluene concentration in the inflow revealed an increase in total toluene mass degraded per unit time. The toluene removal efficiency per unit volume, on the other hand, declined with increasing concentration in the inflow (see Table 1). This is actually expected for inflow concentrations $C_{T o l}^{i n}$ that are considerably larger than the halfsaturation concentration $K_{t o l}$ of toluene. In this concentration range, the turnover hardly increases with increasing concentration, so that the pseudo first-order coefficient $\frac{1}{Y} \cdot \frac{\mu_{\max }}{c_{t o l}+K_{t o l}}$ decreases.

We estimated the yield by two independent approaches leading to comparable results. In the first approach, we compared the amount of oxygen consumed per toluene degraded, $f_{\text {ox }}$. For the complete mineralization of toluene to carbon dioxide and water, a value of 9 mol $_{\mathrm{O}_{2}} \mathrm{~mol}_{\mathrm{Tol}}^{-1}$ is applied, which does not account for cell maintenance, carbon assimilation, and growth. Under growth conditions, however, bacteria oxidize only a part of the substrate to carbon dioxide to gain energy, while they assimilate the other part of the substrate-carbon into new biomass, in which carbon is more reduced than in $\mathrm{CO}_{2}$ (Rittmann and McCarty 2001). This reduces the amount of oxygen needed to degrade one unit of toluene under growth conditions. The $f_{o x}$-values obtained for the different experiments fell in the range of 2.6-5.5 $\mu \mathrm{mol}_{\mathrm{Tol}} \mu \mathrm{mol}_{\mathrm{O}_{2}}^{-1}$, indicating carbon assimilation efficiencies of approximately 0.4-0.7. As can be seen from Fig. 3d, there is a positive relationship between $f_{o x}$ and flow velocity. The faster the toluene is transported through the sediment, the less efficient is the substrate carbon converted into biomass. However, in total more toluene is degraded at higher flow rates and a higher standing stock of bacterial biomass is obtained (Fig. 3e). No pronounced differences were obtained for $f_{o x}$ with changing toluene concentrations in the inflow (Fig. 3d).

In our second approach, the yield was calculated via the measured cell biomass produced from the toluene degraded. Based on microscopic measurements of cell dimensions (length and width), subsequent conversion into biovolume, and the assumption that carbon makes up $50 \%$ of the cell's dry mass, the cell yields were converted into $\mu \mathrm{mol}_{\text {cell-carbon }} \mu \mathrm{mol}_{\text {Tol }}^{-1}$. Doing so, and taking into account attached cells, as well as cells suspended in pore-water and continuously flushed out of the sediment columns, we again estimated a range of carbon assimilation efficiencies of 0.4-0.7.

The carbon assimilation efficiencies in the batch experiments were found to be around $0.4-0.5$ and could only be calculated via cell counts since there was a continuous supply of oxygen from the headspace in the batch bottles. Carbon assimilation efficiencies were therefore slightly lower in batch (0.4-0.5) than in the flow-through sediment microcosms (0.4-0.7). This is surprising, since high carbon assimilation efficiencies of $>0.5$ are generally reported for batch and chemostat systems (Ho and Payne 1979; Payne and Wiebe 1978, and references therein).

Both yield estimates obtained in our experiments are subject to uncertainty. Estimation of cell carbon via cell measurements in the microscope and translation into cell carbon is based on a number of assumptions, such as the carbon content of the dry biomass. Conversely, to obtain $f_{o x}$ values, we used mean oxygen values within the sediment columns ignoring the potential concentration gradients along the three points of measurement (bottom, middle, top; Fig. 1). The following additional points may affect the reliability and comparability of the yield estimates. First, the yield was calculated over the entire duration of the experiments, up to 3 days in the batch experiments and up to 9 days in the column experiments, including the stationary phase in the batch systems and the quasi steady-state phase in the microcosms. Second, in the batch experiments, the cultures received a single donation of substrate at $t_{0}$ which then was continuously depleted, while in the flowthrough systems substrate was supplied continuously causing a concentration gradient from the column inlet to the outlet. Third, in the batch system, cells generally 
stop growing when the substrate was depleted. In the flow-through systems, growth decelerated when the maximum cell density was reached, which is termed the carrying capacity in ecology (del Monte-Luna et al. 2004). Finally, if we consider that the substrate is first converted to intermediates which are subsequently utilized for assimilation and mineralization, the overall yield changes during the experiment and can only be deduced by fitting a model that account for a generic intermediate, unless all possible metabolites are monitored. Nevertheless, our experiments provide strong evidence that in flow-through systems cells attached to a solid matrix are more efficiently converting substrate carbon into biomass than suspended ones.

\section{Suspended and attached cells and carrying capacity}

Batch systems are closed and optimized systems containing only suspended bacteria, and thus don't resemble the conditions in aquifers. The column systems are a step closer to field conditions as they represent flow-through systems containing both a mobile pore-water phase and an immobile sediment matrix with a solid-to-water ratio close to aquifer conditions (Hofmann et al. 2016). The distribution of cells between these two phases have been reported to depend on several factors including nutrient concentration in the pore-water, flow velocity, surface structure, and nutrient content of the sediment particles (Banfield and Hamers 1997; Banfield et al. 1999; Bennet et al. 2000, 2001; Carson et al. 2009; Ehrlich 1996; Marshall 1988; Mauck and Roberts 2007; Rogers and Bennet 2004; Tuschewitzki et al. 1992; Grösbacher et al. 2016). As a consequence, bacterial growth in flow-through sediment systems can only be monitored if changes in cell numbers are followed in both the attached and suspended populations. Cells that are continuously washed out may be a major contribution to the overall biomass balance. In our column systems, about $98-99 \%$ of the cells were found attached to the sediment at any time during the experiment; such numbers are also found in most aquifers (Alfreider et al. 1997; Griebler et al. 2002; Lehman et al. 2001a, b).

In all column experiments performed in this study, the amount of attached cells plateaued at a constant level after an initial growth phase, which indicates that the columns had a maximum carrying capacity for attached cells (Zhou et al. 2012). The carrying capacity showed an increasing trend with the amount of toluene degraded in the individual experiments. This suggests that the utilizable mass flux of substrate contributes to the control of the carrying capacity for attached bacteria. While the number of attached cells plateaued at concentrations of $0.9 \times 10^{8}$ to $27 \times 10^{8}$ cells $\mathrm{mL}_{\mathrm{sed}}^{-1}$ in the different experiments, $2 \times 10^{6}$ to $4 \times 10^{6}$ cells $\mathrm{mL}^{-1}$ were detected in the column outlets under stable experimental conditions. In fact, the ratio of attached to suspended cells was highest at the lowest substrate concentrations and vice versa, a pattern that is well known from aquatic sediments including aquifers (Harvey et al. 1984; Bengtsson 1989; Griebler et al. 2001, 2002).

Once the cells had reached the carrying capacity on the sediment, newly formed cells were released into the pore-water where they are transported and occasionally washed out of the columns. Over the course of the entire experiments (max duration of 9 days), this outwash corresponded to about 20-93\% of all newly grown cells. An important finding was that growthfacilitated release of attached cells into the mobile phase was very strain-specific. While $P$. putida F1 cells growing on the sediment substantially released cells into the pore-water, fewer cells were released by the natural community and the fewest by the denitrifying strain $A$. aromaticum EbN1. A significant contribution from budding and detachment cells to the free floating cells in pore-water under growth conditions has been repeatedly observed in earlier studies (e.g., Clement et al. 1997; Murphy et al. 1997; Yolcubal et al. 2002; Jordan et al. 2004) and referred to as cell-division mediated transport by Murphy and Ginn (2000). The finding that the vast majority of cells is attached to the sediment surface suggests that suspended cells have only a minor impact on the overall contaminant degradation, which was confirmed by reactive-transport simulations. In our experiments, the residence time of the pore-water in the columns was rather short (between 6.5 and $38.5 \mathrm{~min}$ depending on the flow rate). Still, even if suspended cells do not significantly contribute to contaminant degradation at anywhere within an aquifer, the continuous release of new-grown cells from the sediment to the mobile aqueous phase, which has been observed in our study, increases the ability of bacteria to spread and colonize new sediment surfaces. This may be an important mechanism to establish a high 
biodegradation potential throughout an aquifer, which would be needed if hydrological fluctuations change the spatial distribution of the contaminants.

Microbes always grow towards the substrate source, even against strong currents. To reduce the effects of steep gradients on the quantification of turnover rates, we have chosen very small and short sediment columns. However, while we observed no significant gradient in cell numbers in most experiments, a distinct gradient in cell density was obvious in experiment $\mathrm{B}$, with the highest cell density in the bottom part of the column near the inlet port for toluene and oxygen. The fact that the oxygen concentrations hardly differed between the bottom, middle, and top parts of the columns in all experiments indicates that microbial activity was indeed mainly restricted to the bottom (inflow) part of the columns, once a stable community of attached bacteria had developed. Interestingly, the continuous release of new cells mainly produced at the column inlet into the pore-water and its subsequent attachment to sediment particles downgradient, revealed a similar density of attached cells throughout the columns in most of the experiments. We may also not exclude the existence of steep small-scale biomass gradients at the column inlet that were beyond our spatial sampling resolution.

\section{Reactive-transport modeling}

The combined measurement of attached and suspended cells enabled us to develop a quantitative model, which explicitly accounts for the release of new-grown cells from the sediments to the mobile aqueous phase by the dynamic growth-dependent detachment rate $r_{\text {daughter }}$. The reactive-transport simulations revealed that suspended cells were irrelevant for toluene degradation in the column experiments. Although it is well known that bacteria transported in porous media are important as seed banks in aquifers (Griebler et al. 2014) and play an important role in partitioning between the mobile aqueous phase and the sediment surface (e.g. Ginn et al. 2002; Tufenkji 2007; Scheibe et al. 2011; Zhou et al. 2012), the finding that the majority of bacteria in aquifers is attached to the sediment matrix led to the situation that the biomass catalyzing the breakdown of organic contaminants is usually treated as immobile species in reactivetransport models, and the presence of bacteria suspended in the mobile aqueous phase is neglected (e.g.,
Barry et al. 2002; Schirmer et al. 2000; Prommer et al. 2006, 2009). Moreover, the majority of studies on the transport of microorganisms in porous media was conducted under non-growth conditions and aimed at improving the understanding of the physical processes (e.g. straining and filtration) that govern microbial transport in porous media, which are important for the fate and behavior of pathogens in groundwater. A few studies, investigating the effect of biological processes on microbial transport in porous media, indicated that microbial growth strongly affects the partitioning of bacteria between the aqueous phase and the sediment surface in addition to physical processes (e.g., Clement et al. 1997; Murphy et al. 1997; Yolcubal et al. 2002; Jordan et al. 2004; Eckert et al. 2015). In all of these studies an increase in the number of suspended bacteria was observed after the addition of a growth substrate to the system.

While the results obtained in this study clearly highlight the flow velocity, the substrate concentration, and the electron-acceptor limitation as different drivers of microbial contaminant degradation in liquid batch and flow-through sediment systems, the data obtained from our lab experiments with single degrader strains should be translated to the field situation with caution. In situ, additional factors like food web interactions, grazing, or competition for resources as well as multiple limitations play an important role within natural microbial communities (Konopka 2000; Griebler and Lueders 2009; Griebler et al. 2014; Meckenstock et al. 2015). Numbers of attached bacteria as high as $10^{8}$ to $10^{9}$ cells $\mathrm{mL}^{-1}$ sediment as established in our column experiments are hardly observed in aquifers. Even at comparable high or even higher toluene concentrations, cell densities are typically 1-2 orders of magnitude lower (Winderl et al. 2008; Anneser et al. 2010). In our studies, the tested microbial community, obtained from natural aquifer sediments, degraded toluene at a slower pace than the specialized toluene-degrading strains $P$. putida $\mathrm{F} 1$ and A. aromaticum EbN1. This is most probably due to the fact that in natural communities, only a small fraction of the community is metabolically active while the majority is in an inactive resting state (Shade et al. 2012). Moreover, only a portion of the active cells in a community might be capable of utilizing petroleum hydrocarbons like toluene, which are toxic at elevated concentrations to many bacterial species (Castillo and Ramos 2007; Herzyk et al. 
2013, 2017; Okpokwasili and Nweke 2005; Vecht et al. 1988). Assuming that the toluene-degrading species have a low overall abundance at the beginning of the experiment, the onset of pronounced toluene degradation is delayed until these toluene degrading species reach sufficient cell numbers. We should never expect that degraders under in situ conditions reach the carbon assimilation efficiencies and maximum growth rates observed in the lab. Nonetheless, our results are an important step towards a better understanding of ecological drivers of organic-contaminant biodegradation.

\section{Conclusions}

A recent review by Meckenstock et al. (2015) highlights that many common concepts regarding degradation of organic contaminants by microbes in aquifers need considerable revision. One important aspect is that our lab-based knowledge, which is mainly derived from batch experiments, is of limited use in understanding and predicting processes in a natural, heterogeneous, complex, open flow-through sediment system. Our study underlines that degradation and associated growth rates are insufficiently predicted using laboratory batch experiments, which can lead to overestimating anticipated in situ biodegradation. Also, only flow-through sediment systems allow for an independent assessment of attached and suspended cells. As was found, attached bacteria are responsible for the majority of the observed biodegradation. While attached cells were mainly responsible for toluene degradation, the release of cells into the pore water causes permanent inoculation of the aquifer downstream. In consequence, the ratio of sediment to water is crucial when setting up laboratory experiments representative of field conditions. Finally, mass transfer limitation is an important process controlling toluene biodegradation that cannot be reproduced with laboratory batch experiments. We are convinced that mathematical models that simulate biodegradation and bacterial growth in aquifers will greatly be improved in their accuracy when they are calibrated by data derived from flow-through sediment microcosms and/or directly from field studies at appropriate spatial and temporal resolution.
Acknowledgements This study was funded by the German Research Foundation (DFG) under Grants GR 2107/3-1 and Ci26/9-1.

Open Access This article is distributed under the terms of the Creative Commons Attribution 4.0 International License (http:// creativecommons.org/licenses/by/4.0/), which permits unrestricted use, distribution, and reproduction in any medium, provided you give appropriate credit to the original author(s) and the source, provide a link to the Creative Commons license, and indicate if changes were made.

\section{References}

Abuhamed T, Bayraktar E, Mehmetoglu T, Mehmetoglu U (2004) Kinetics model for growth of Pseudomonas putida F1 during benzene, toluene and phenol biodegradation. Process Biochem 39:983-988

Alagappan G, Cowan RM (2004) Effect of temperature and dissolved oxygen on the growth kinetics of Pseudomonas putida $\mathrm{F} 1$ growing on benzene and toluene. Chemosphere 54:1255-1265

Alfreider A, Krössbacher M, Psenner R (1997) Groundwater samples do not reflect bacterial densities and activity in subsurface systems. Water Res 31:832-840

Anneser B, Einsiedl F, Meckenstock RU, Richters L, Wisotzky F, Griebler C (2008) High-resolution monitoring of biogeochemical gradients in a tar oil-contaminated aquifer. Appl Geochem 23:1715-1730

Anneser B, Pilloni G, Bayer A, Lueders T, Griebler C, Einsiedl F, Richters L (2010) High resolution analysis of contaminated aquifer sediments and groundwater-what can be learned in terms of natural attenuation? Geomicrobiol J 27:130-142

Ballarini E, Beyer C, Bauer RD, Griebler C, Bauer S (2014) Model based evaluation of a contaminant plume development under aerobic and anaerobic conditions in $2 \mathrm{~d}$ benchscale tank experiments. Biodegradation 25:351-371

Banfield JF, Hamers RJ (1997) Processes at minerals and surfaces with relevance to microorganisms and prebiotic synthesis. Rev Mineral 35:81-122

Banfield JF, Barker WW, Welch SA, Taunton A (1999) Biological impact on mineral dissolution: application of the lichen model to understanding mineral weathering in the rhizosphere. Proc Natl Acad Sci USA 96:3404-3411

Barry DA, Prommer H, Miller CT, Engesgaard P, Brun A, Zheng C (2002) Modelling the fate of oxidisable organic contaminants in groundwater. Adv Water Resour 25:945-983

Bauer R, Zhang Y, Maloszewski P, Meckenstock RU, Griebler C (2008) Mixing controlled biodegradation in a toluene plume - results from two-dimensional laboratory experiments. J Contam Hydrol 96:150-168

Bauer RD, Rolle M, Bauer S, Eberhardt C, Grathwohl P, Kolditz O, Meckenstock RU, Griebler C (2009) Enhanced biodegradation by hydraulic heterogeneities in petroleum hydrocarbon plumes. J Contam Hydrol 105:56-68 
Bayer A, Drexel R, Weber N, Griebler C (2016) Quantification of aquatic sediment prokaryotes-a multiple-steps optimization testing sands from pristine and contaminated aquifers. Limnologica 56:6-13

Bengtsson G (1989) Growth and metabolic flexibility in groundwater bacteria. Microb Ecol 18:235-248

Bennett PC, Hiebert FK, Rogers JR (2000) Microbial control of mineral-groundwater equilibria: macroscale to microscale. Hydrogeol J 8:47-62

Bennett PC, Rogers JR, Choi WJ, Hiebert FK (2001) Silicates, silicate weathering, and microbial ecology. Geomicrobiol J 18:3-19

Bombach P, Chatzinotas A, Neu TR, Kästner M, Lueders T, Vogt C (2009) Enrichment and characterization of a sulfate-reducing toluene-degrading microbial consortium by combining in situ microcosms and stable isotope probing techniques. FEMS Microbiol Ecol 71:237-246

Carson JK, Campbell L, Rooney D, Clipson N, Gleeson DB (2009) Minerals in soil select distinct bacterial communities in their microhabitats. FEMS Microbiol Ecol 67:381-388

Castillo Td, Ramos JL (2007) Simultaneous catabolite repression between glucose and toluene metabolism in Pseudomonas putida is channeled through different signaling pathways. J Bacteriol 189:6602-6610

Chapelle FH (2000) Ground-water microbiology and geochemistry. Wiley, New York

Clement TP, Peyton BM, Skeen RS, Jennings DA, Petersen JN (1997) Microbial growth and transport in porous media under denitrification conditions: experiments and simulations. J Contam Hydrol 24:269-285

del Giorgio PA, Cole JJ (1998) Bacterial growth efficiency in natural aquatic systems. Ann Rev Ecol Syst 29:503-541

del Monte-Luna P, Brook BW, Zetina-Rejon MJ, Cruz-Escalona VH (2004) The carrying capacity of ecosystems. Glob Ecol Biogeogr 13:485-495

Ding D (2010) Transport of bacteria in aquifer sediment: experiments and modeling. Hydrogeol J 18:669-679

Dykaar BB, Kitanidis PK (1996) Macrotransport of a biologically reacting solute through porous media. Water Resour Res 32:307-320

Eckert D, Kürzinger P, Bauer R, Griebler C, Cirpka OA (2015) Fringe-controlled biodegradation un-der dynamic conditions: quasi 2-D flow-through experiments and reactivetransport modeling. J Contam Hydrol 172:100-111. https:// doi.org/10.1016/j.jconhyd.2014.11.003

Egli T (2010) How to live at very low substrate concentration. Water Res 44:4826-4837

Ehrlich HL (1996) How microbes influence mineral growth and dissolution. Chem Geol 132:5-9

Evans PJ, Mang DT, Kim KS, Young LY (1991) Anaerobic degradation of toluene by a denitrifying bacterium. Appl Environ Microbiol 57:1139-1145

Fischer A, Bauer J, Meckenstock RU, Stichler W, Griebler C, Maloszewski P, Kästner M, Richnow HH (2006) A multitracer test proving the reliability of Rayleigh equationbased approach for assessing biodegradation in a BTEX contaminated aquifer. Environ Sci Technol 40:4245-4252

Foght J (2008) Anaerobic biodegradation of aromatic hydrocarbons: pathways and prospects. J Mol Microbiol Biotechnol 15:93-120
Ginn TR, Wood BD, Nelson KE, Scheibe TD, Murphy EM, Clement TP (2002) Processes in microbial transport in the natural subsurface. Adv Water Resour 25:1017-1042

Griebler C, Lueders T (2009) Microbial biodiversity in groundwater ecosystems. Freshw Biol 54:649-677

Griebler C, Mindl B, Slezak D (2001) Combining DAPI and SYBR Green II for the enumeration of total bacterial numbers in aquatic sediments. Int Rev Hydrobiol 86:453-465

Griebler C, Mindl B, Slezak D, Geiger-Kaiser M (2002) Distribution patterns of attached and suspended bacteria in pristine and contaminated shallow aquifers studied with an in situ sediment exposure microcosm. Aquat Microb Ecol 28:117-129

Griebler C, Malard F, Lefébure T (2014) Current developments in groundwater ecology-from biodiversity to ecosystem function and services. Curr Opin Biotechnol 27:159-167

Grösbacher M, Spicher S, Bayer A, Obst M, Karwautz C, Pilloni G, Wachsmann M, Scherb H, Griebler C (2016) Organic contaminations versus mineral properties: competing selective forcesshaping bacterial community assembly in aquifer sediments. Aquat Microb Ecol 76:243-255

Harvey RW, Smith RL, George L (1984) Effect of organic contamination upon microbial distribition and heterotrophic uptake in a Cape Cod, Mass., aquifer. Appl Environ Microbiol 48:1197-1202

Herzyk A, Maloszewski P, Qiu S, Elsner M, Griebler C (2013) Intrinsic potential for immediate biodegradation of toluene in a pristine, energy-limited aquifer. Biodegradation 25:325-336

Herzyk A, Fillinger L, Larentis M, Qiu S, Maloszweski P, Hünniger M, Schmidt SI, Stumpp C, Marozava S, Knappett PSK, Elsner M, Meckenstock RU, Lueders T, Griebler C (2017) Response and recovery of a pristine groundwater ecosystem impacted by toluene contamination - a mesoscale indoor aquifer experiment. J Contam Hydrol 207:17-30

Hesse F, Radu FA, Thullner M, Attinger S (2009) Upscaling of the advection-diffusion-reaction equation with monod reaction. Adv Water Resour 32:1336-1351

Ho KP, Payne WJ (1979) Assimilation efficiency and energy contents of prototrophic bacteria. Biotechnol Bioeng 21:787-802

Hofmann R, Griebler C (2018) DOM and bacterial growth efficiency in oligotrophic groundwater - absence of priming and co-limitation by organic carbon and phosphorus. Aquat Microb Ecol 81:55-71

Hofmann R, Grösbacher M, Griebler C (2016) Mini sediment columns and two-dimensional sediment flow-through microcosms: versatile experimental systems for studying biodegradation of organic contaminants in groundwater ecosystems. In: McGenity TJ et al (eds) Hydrocarbon and lipid microbiology protocols. Springer, Berlin. https://doi. org/10.1007/8623_2016_210

Jordan FL, Sandrin SK, Frye RJ, Brusseau ML, Maier RM (2004) The influence of system complexity on bacterial transport in saturated porous media. J Contam Hydrol 74:19-38

Jorgensen C, Flyvbjerg J, Arvin E, Jensen BK (1995) Stoichiometry and kinetics of microbial toluene degradation under denitrifying conditions. Biodegradation 6:147-156 
Kelly WR, Hornberger GM, Herman JS, Mills AL (1996) Kinetics of btx biodegradation and mineralization in batch and column systems. J Contam Hydrol 23:113-132

Konopka A (2000) Microbial physiological state at low growth rate in natural and engineered ecosystems. Curr Opin Microbiol 3:244-247

Lehman RM, Colwell FS, Bala GA (2001a) Attached and unattached microbial communities in a simulated basalt aquifer under fracture- and porous-flow conditions. Appl Environ Microbiol 67:2799-2809

Lehman RM, Roberto FF, Earley D, Bruhn DF, Brink SE, O'Connel SP, Delwiche ME, Colwell FS (2001b) Attached and unattached bacterial communities in a 120-meter corehole in an acidic, crystalline rock aquifer. Appl Environ Microbiol 67:2095-2106

Mak KS, Griebler C, Meckenstock RU, Liedl R, Peter A (2006) Combined application of conservative transport modelling and compaound-specific carbon isotope analyses to assess in situ attenuation of benzene, toluene, and o-xylene. J Contam Hydrol 88:306-320

Marshall KC (1988) Adhesion and growth of bacteria at surfaces in oligotrophic habitats. Can J Microbiol 34:503-506

Mauck BS, Roberts JA (2007) Mineralogic control on abundance and diversity of surface-adherent microbial communities. Geomicrobiol J 24:167-177

Meckenstock RU, Mouttaki H (2011) Anaerobic degradation of non-substituted aromatic hydrocarbons. Curr Opin Biotechnol 22:406-414

Meckenstock RU, Safinowski M, Griebler C (2004) Anaerobic degradation of polycyclic aromatic hydrocarbons. FEMS Microbiol Ecol 49:27-36

Meckenstock RU, Lueders T, Griebler C, Selesi D (2010) Microbial hydrocarbon degradation at coal gasification plants. In: Timmis KN (ed) Handbook of hydrocarbon and lipid microbiology. Springer, Berlin. https://doi.org/10. 1007/978-3-540-77587-4_167

Meckenstock RU, Elsner M, Griebler C, Lueders T, Stumpp C, Dejonghe W, Bastiaens L, Sprigael D, Smolders E, Boon N, Agathos S, Sorensen SR, Aamand J, Albrechtsen H-J, Bjerg P, Schmidt SI, Huang W, van Breukelen B (2015) Biodegradation: updating the concepts of control for microbial clean-up in contaminated aquifers. Environ Sci Technol 49:7073-7081

Mellage A, Eckert D, Grösbacher M, Cirpka OA, Griebler C (2015) Dynamics of aerobic toluene degraders in flowthrough systems under growth and starvation conditions. Evaluating the performance of water purification in a vegetated groundwater recharge basin maintained by shortterm pulsed infiltration events. Water Sci Technol 72 (11): 1912-1922. https://doi.org/10.2166/wst.2015.400

Murphy EM, Ginn TR (2000) Modeling microbial processes in porous media. Hydrogeol J 8:142-158

Murphy EM, Ginn TR, Chilakapati A, Resch CT, Phillips JL, Wietsma TW, Spadoni CM (1997) The influence of physical heterogeneity on microbial degradation and distribution in porous media. Water Resour Res 33:1087-1103

Okpokwasili GC, Nweke CO (2005) Microbial growth and substrate utilization kinetics. Afr J Biotech 5:305-317

Payne WJ, Wiebe WJ (1978) Growth yield and efficiency in chemosynthetic microorganisms. Annu Rev Microbiol 32:155-183
Prommer H, Tuxen N, Bjerg PL (2006) Fringe-controlled natural attenuation of phenoxy acids in a landfill plume: integration of field-scale processes by reactive transport modeling. Environ Sci Technol 40:4732-4738

Prommer H, Anneser B, Rolle M, Einsiedl F, Griebler C (2009) Biogeochemical and isotopic gradients in a BTEX/PAH contaminant plume: model-based interpretation of a highresolution field data set. Environ Sci Technol 43:8206-8212

Rabus R, Widdel F (1994) Anaerobic degradation of ethylbenzene and other aromatic hydrocarbons by new denitrifying bacteria. Arch Microbiol 163:96-103

Reardon KF, Mosteller DC, Bull Rogers JD (2000) Biodegradation kinetics of benzene, toluene, and phenol as single and mixed substrates for Pseudomonas putida F1. Biotechnol Bioeng 69:385-400

Rittmann BE, McCarty PL (2001) Environmental biotechnology: principles and applications. McGraw-Hill, New York

Rogers JR, Bennett PC (2004) Mineral stimulation of subsurface microorganisms: release of limiting nutrients from silicates. Chem Geol 203:91-108

Rüegg I, Hafner T, Bucheli-Witschel M, Egli T (2007) Dynamics of benzene and toluene degradation in Pseudomonas putida $\mathrm{f} 1$ in the presence of the alternative substrate succinate. Eng Life Sci 7:331-342

Scheibe TD, Hubbard SS, Onstott TC, DeFlaun MF (2011) Lessons learned from bacterial transport research at the south oyster site. Ground Water 49:745-763

Schirmer M, Molson JW, Frind EO, Barker JF (2000) Biodegradation modelling of a dissolved gasoline plume applying independent laboratory and field parameters. J Contam Hydrol 46:339-374

Shade A, Peter H, Allison SD, Baho DL, Berga M, Bürgmann H, Huber DH, Langenheder S, Lennon JT, Martini JBH, Matulich KL, Schmidt TM, Handelsman J (2012) Fundamentals of microbial community resistance and resilience. Front Microbiol. https://doi.org/10.3389/fmicb.2012. 00417

Silva-Castro GA, Rodelas B, Perucha C, Laguna J, López JG, Calvo C (2013) Bioremediation of diesel-polluted soil using biostimulation as post-treatment after oxidation with fenton-like reagents: assays in a pilot plant. Sci Total Environ 445-446:347-355

Simoni SF, Schafer A, Harms H, Zehnder AJB (2001) Factors affecting mass transfer limited biodegradation in saturated porous media. J Contam Hydrol 50:99-120

Tufenkji N (2007) Modeling microbial transport in porous media: traditional approaches and recent developments. Adv Water Resour 30:1455-1469

Tuschewitzki GJ, Langer B, Otremba H (1992) Interaction between humic substances and microorganisms. Progress in hydrogeochemistry. Springer, Berlin, pp 358-365

Vecht SE, Platt MW, Er-El Z, Goldberg I (1988) The growth of Pseudomonas putida on m-toluic acid and on toluene in batch and in chemostat cultures. Appl Microbiol Biotechnol 27:587-592

Vieth A, Richnow HH, Meckenstock RU, Gödeke S, Weiß H, Schirmer M, Kästner M (2004) Monitoring in situ biodegradation of benzene and toluene by stable carbon isotope fractionation. Environ Toxicol Chem 24:51-60 
Widdel F, Bak F (1992) Gram-negative mesophilic sulfate reducing bacteria. The prokaryotes. Springer, New York, pp 3352-3378

Winderl C, Anneser B, Griebler C, Meckenstock RU, Lueders T (2008) Depth-resolved microbial community structure and quantitative localization of anaerobic toluene degraders in distinct redox zones of a tar-oil contaminant plume. Appl Environ Microbiol 74:792-801

Yolcubal I, Pierce SA, Maier RM, Brusseau ML (2002) Biodegradation during contaminant transport in porous media: V. The influence of growth and cell elution on microbial distribution. J Environ Qual 31:1824-1830

Yu HB, Kim BJ, Rittmann BE (2001) A two-step model for the kinetics of btx degradation and intermediate formation by Pseudomonas putida $\mathrm{f} 1$. Biodegradation 12:465-475

Zhou Y, Kellermann C, Griebler C (2012) Spatio-temporal patterns of microbial communities in a hydrologically dynamic pristine aquifer. FEMS Microb Ecol 81:230-242 